\title{
THE HOMICIDE COURTS OF ANCIENT ATHENS.
}

Early Athens, like other primitive communities, was ruled not by laws, but by customs. The custom in any matter was what everyone did under similar circumstances. As Plato says: "They [primitive men] could hardly have wanted lawyers as yet; nothing of that sort was likely to have existed in those days, for they had no letters at this early stage; they lived according to custom and the laws of their fathers, as they are termed." I In other words, in the absence of formal laws, justice was synonymous with precedent. At first, crimes, which later were looked upon as offenses against the state, were merely private affairs. Thus murder was only a private offense against the victim and his surviving kinsmen. To have slain a man was a misfortune, for it entailed serious consequences. In the Homeric civilization the kinsmen might or might not accept wergeld as compensation for the loss and the idea of accepting it was; regarded as a perfectly justifiable alternative to exacting blood, vengeance. By giving presents to the relatives of the murdered man, the offender not only could repair the loss inflicted upon then by the death of their kinsman, but he could also appease their anger, as the pleasure of revenge would tend to alleviate their indignation and loss and the humiliation of their enemy would help to heal their resentment. Furthermore, the accept- ance of compensation was a matter of expediency; for it saved the injured party from the risks involved in carrying out the blood-feud, i. e., the uncertainty of the issue. and similar contingencies.

In the Homeric poems, then, the murderer either paid wergcld and was suffered to remain in peace at home or he had to flee the country. ${ }^{2}$ Thus Ajax reproaches Achilles for not wishing to be appeased: "Yet doth a man accept recompense.

'Laws, III 680 A (Jowett's Transiation).

"Pausanias, $T, 28$, 10, in mentioning the trial of Theseus for justifiable" murder, says: "In former days, before the acquittal of Theseus, the custom was that every manslayer either fled the country, or if he stayed, was slain even as he slew." (Frazer's Translation.) 
of his brother's murderer or for his dead son; and so the manslayer for a great price abideth in his own land, and the kinsman's heart is appeased, and his proud soul, when he hath taken the recompense." 3 It seems, however, to have been safer to flee than to try to pay the recompense. Thus Odysseus says: "For whoso has slain but one man in a land, even one that leaves not many behind him to take up the feud for him, turns outlaw and leaves his kindred and his own country." 4 Even then he might be pursued by the relatives or friends of the slain man. The Homeric poems contain several instances of men who became outlaws for having slain their man." Only by slow degrees and long after Homeric times did such a simple notion as blood revenge yield to a system of punishment wherein the private avenger became metamorphosed into a plaintiff before a judge appointed by the community. It was a long time before the state took the initiative in counselling the people to do what was customary and in seeing that this was done. This was largely for the reason that for a long period of time there was little semblance to a state; but it was also partly due to the fact that slaves of custom were not averse to doing what was usual and so needed no incentive. However, in course of time, breaches of custom might occur which would be serious enough to shock the community as a whole into enforcing the existing custom. When such breaches became habitual, customary laws (nomoi) would follow. Since not everyone would know exactly what these laws were, a privileged class would arise which possessed

- Iliad, IX, 632 sq. (Translation of Lang, Leaf and Myers.)

Odyssey, XXIII, Ir8 sq. (Transtation of Butcher and Lang.)

E. g. Odyssey, XV, 278 .

- E. g. Odyssey, XV, 272 sq., where Theoclymenus flees for having slain a kinsman; Iliad, II, 66I sq. where Tlepolemus slays his granduncle and flees over the seas; ibid., XV, 429 sq., where. Lycurgus slew a man of Cythera; Odysscy, XIII, 259 sq. where Odysseus deceitfully says he has become an outlaw for slaying Orsilochus. A homicide trial was represented on the shield of Achilles, Iliad. XVIII, 497-508; strife had arisen between two men as to the price of a slain man; the slayer avows he has paid all, but the victim's kinsman says he has received naught; elders, seated on a circle of polished stone, are the judges and, strangely enough, two talents of gold lie in the midst; on their-significance, $c f$. Thonissem, $L e$ droit pénal . de la république Athcriente (1875), p. 27.

'See Leist, Graeco-italische Rechtsgeschichte' (1884), Sec: 50, especially pp. 375 and 381 . 
this knowledge exclusively. It was in this way, then, that laws came into being and the earlier blood-feuds and blood-money were slowly abolished. Still later different degrees of guilt were distinguished and, finally, when the alphabet became known; these customary laws were written down on stone and thus codified law came into existence. This, in the case of Athens, first came about, according to Aristotle, ${ }^{8}$ in the days of Draco. A written code was the necessary condition of exact justice and, furthermore, it was the first concession, historically speaking, which was wrung from the aristocracy by the people.

The ease with which blood-money was accepted among the Homeric Greeks has been explained as resulting from the belief in the disembodied existence of the soul in Hades, where it was supposed to live on without strong passions and without power to injure the home. The later Greek custom of demanding a life for a life, on the other hand, has been explained as the result of the change in ideas of the hereafter, which slowly developed after Homer's time and which attributed a far greater activity to the dead. Now the soul carried below a longing for revenge and it could still hover about its earthly haunts and annoy its slayer and incite its kinsmen to avenge it. This idea that the ghost of a murdered man could still terrify the living is a myth common to the folklore of many peoples and it seems to have been held in Athens during the fifth and fourth centuries B. C. ${ }^{9}$ Thus Orestes, in the Choephorae of Aeschylus, says Apollo had told him that if he did not slay his father's murderer he must atone for it with his life and that the Furies springing from his father's blood, would assault him:

"For the dark shafts of those beneath the earth,

(The slain who cry for vengeance to their kin.)

With frenzy wild, and groundless fear at night,

Disturb and harass his distracted soul," etc.."

'The Constitution of Athens, $4 \mathrm{I}, 2$. In this passage he says that Draco's - laws were the first to be written down.

- So E. Schmidt, Die Ethik der alten Griechen (1882), 11, 125,sq.; E. Rohde, Psyche (1894), pp. 8 sq., 238 and 260; cf. his Paralipomena (in Rheinisches Museum für Philologie, $1895, \mathrm{pp}$. ig sq.); 0 . Müller Aeschylos' Eunteniden, p. T45, who believes with Rohde that wergeld grew out of the expiation of the angry spirit by the sacrifice of an animal.

"286-287 (Swanwick's. Translation). 
He thus attributes a Fury or Erinys to the heinous crime of a man who neglects the duty of avenging the soul of the slain man; in other words the dead man's soul turns its anger against its relative. Plato has a similar notion that if the next of kin does not proceed against the murderer, pollution shall fall upon his head and the victim shall call for vengeance upon him. ${ }^{31}$

The Homeric notion of blood-revenge was not peculiar to the early Greeks but was common to many of the early IndoEuropean peoples and is still found among most primitive folk. Before tracing the development of homicide laws among the Greeks it will be instructive to cite examples of this early idea elsewhere. ${ }^{12:}$ There are indications of it in early India, though no mention of it is found in the Sutras. ${ }^{13}$ In China Confucius affirmed the duty of avenging the murder of a father or a brother. ${ }^{14}$ In Japan the murderer was expected to be slain by the surviving relative or else to flee, in which latter case he was despised by his companions. ${ }^{15}$ Among the ancient Iranians bloodrevenge survived the establishment of courts. ${ }^{18}$ Among the Hebrews it existed during the period of the Judges and Kings and even later. Wellhausen says that under the Old Kingdom "The administration of justice was at best but a scanty supplement to the practice of self-help." 17 In the book of Numbers, the Lord said to Moses: "The revenger of blood himself shall

"Laws, IX, 866. On page 865 he mentions "an ancient tale" to the effect that the murdered man's soul when newly dead, is angry with his slayer, and when he sees him walking about in his accustomed haunts, becomes disordered: this disorder of the soul of the slain man, helped on by the guilty recollection of the murderer, is communicated to the latter with such overwhelming force that he has to get away for a year from the places belonging to the victim.

${ }^{23}$ Most of the following examples and authorities are taken from Westermarck, The Origin and Development of Moral Ideas $\mathrm{x},(\mathrm{rg06}), \mathrm{ch}$. XX, pp. 477 sq.

${ }^{2}$ See Leist, Alt-arisches Jus Gentium (1889), p. 422.

"See Legge, The Chinese Classics ( $1893-1895$ ), $\mathrm{I}$, iii.

${ }^{23}$ See T. Dautremer, The Vendetta or Legal Revenge in Japats, in Transactions Asiatic Society of Japan, XIII (I885), p. 83 ; a similar custom prevailed in Corea: see W. E. Griffs, Corea (1882), p. 227.

" See Geiger, Civilization of the Eastern Iranians in Ancient Times (1885-1886), II, 31 sq.

"Prolegomena to the History of Israel, p. $46 \%$. 
slay the murderer; when he meeteth him he shall slay him." 18 Similarly in the Koran we read: "O ye who believe. Retaliation is prescribed for you for the slain." 19 As for the Aryan peoples of Europe, the following data might be given. Among the Romans blood-revenge seems to have been suppressed early, though certain legends indubitably point to its existence and represent it as objectionable. ${ }^{20}$ Among the early Germans Tacitue says compensation for murder was made by paying over a certain number of sheep or cattle. ${ }^{21}$ In the earliest days the. kindred of the victim seem to have had the right of choosing between accepting compensation and exacting revenge; later on public opinion demanded and still later the state required that the blood-feud should not go on if compensation were offered.22 Among the Gauls and early Irish, the judgments of the Druids seem to have been awards based on arbitration, the injured relative being allowed to redress himself as he wished. ${ }^{23}$ In Scotland blood-feuds have lasted into recent times; the Roman Church recognized them by leaving the right hands of male children unchristened, in order that they might deal a more unhallowed and effective blow to enemies. ${ }^{24}$ In England up to the middle of the tenth century a manslayer had the choice of

"XXXV, 19. See the article on Retaliation and Compensation Among the Hebrews, by $\mathrm{D}$. W. Amram of the University of Pennsylvania Law School, in the Jewish Quarterly Review (new series, Vol. II, No. II, IgII, pp. I9I-2II).

II, 173; cf. XVII, 35 (Rodwell's Translation, 1876). Among the modern Arabs the slayer owes his blood to the family of the victim: see Burchchardt, Notes on the Bedouins and Wahabys, p. 85.

- See Mommsen, History of Rome (1894), I, 190.

"Germania, ch. 21.

" See J. R. Keyser, Efterladte Skriften (Christiania, 1865-1867), II, Pt. II, p. 95; Pollock and Maitland, The History of the English Law before the Time of Edward I (I8g8), I, p. 46 sq., cf. Kemble, The Saxoms in England, I, 270, who says that the State in course of time became the arbitrator between the parties "by establishing a tariff by which injuries should be rated, and committing to the State the duty of compelling the injured person to receive, and the wrongdoer to pay, the settled amount."

s See Sir Henry Maine, Early History of Institutions (1875), Lecture II ; d'Arbois de Jubainville, Des attributions judicaires de l'autorité publique chez les Celtes, in the Revue Celtique, VII, 5 ; Ancient Laws and Institutes of Ireland, III, IXXX and IXXXIX.

"See Mackintosh, The History of Civilization in Scotland, II, p. 279. 
paying wergeld or having a feud with the victim's relatives. ${ }^{25}$ In Friesland, Saxony, and Switzerland this custom prevailed down to the sixteenth century. ${ }^{26}$ In Italy it lasted into the sixteenth and seventeenth centuries, ${ }^{27}$ and it still exists. in several European countries, as, e. $g$., in Corsica, ${ }^{28}$ Albania ${ }^{29}$ and Montenegro. ${ }^{30}$ We shall omit examples of its occurrence among halfcivilized and savage communities, ${ }^{31}$ and return to the history and development of the laws governing homicide among the post-Homeric Greeks.

The Greeks throughout their later history lowked upon their laws-especially those framed for the protection of life-as divine in origin. Their early legislators were believed to have been specially inspired by divine power, as, e. g., Lycurgus; the Spartan, by Apollo and Minos, the Cretan, by Zeus. Plato taught that it was a fundamental factor in the prosperity of any state to inculcate this notion. But such a conception of the divine origin of Greek law was not confined to legend nor philosophy. We see a remarkable example of it in the orator Demosthenes, who expresses it to a jury of average Athenians, and so his words represent the typical if not the critical view of the Athenian people. In a passage in the first oration against Aristogeiton, $^{32}$ the orator opposes Laws (nomoi) and nature (physis). While the latter is a thing "irregular, unequal and

- See Pollock \& Maitland, op. cit., I, p. 48. After the Conquest, 2 law against private revenge was passed; see Cherry, Leclures on the Growth of Criminal Law in Ancient Communtities (1890), p. 85.

* See Gunther, ldee der Wiedervergeltung in der Geschichte und Philosophie des Sirafrechts (1889-1895), 1, 202 sq.

"See J. C. L. Simonde de Sismondi, Histoire des républiques ifaliennes du moyen âge (1826), XVI, 456 .

* See Gregorovius, Wonderings in Corsica (1855), 1, pp. 176 sq.

* See S. Gopcevic, Oberalbanien und seine Liga, pp. 322 sq.

"See J. G. Kohl, Reise Nach Istrien, Dalmatien und Montenegro (1851), . I, pp. 406 sq.; G. Popovic, Recht und Gericht in Montenegro (1877), p. 69.

" See Westermarek, op. cit., pp. 479 sq.

- Orat., 25, Secs. 15-16. Throughout this paper I have used the numbering of Demosthenes' orations in Dindorf's edition: orations I-I9, from the fourth edition by $\mathrm{F}$. Blass: orations $20-6 \mathrm{I}$ in the third edition. Oration 25 has been suspected of not being genuine since the time of Dionysius of Halicarnassus; the question of its genuineness, however, does not affect its subject matter. 
peculiar to the individual possessor," laws are "regular, common and the same for all." Men should obey law for many reasons, but especially "because every law is an invention and gift of the gods." He goes on tacitly to identify law and justice. Of course no such identification was ever complete in any Greek State, but was only approximate. 'Still, as G. Lowes Dickinson has observed, ${ }^{33}$ this concept was at the root of all Greek society. It finds expression not only in the passage of Demosthenes mentioned, but is even more explicitly stated in Xenophon's Mcmorabilia, where Socrates maintains without reserve that "what is in conformity with the laws is just." 34 Law was regarded as merely a successful attempt to embody justice in practice, a conviction on which all Greek institutions were based and on which they flourished. Later on critical philosophy overthrew the notion, but its overthrow came with the decline of Greece. According to this Greek idea of the divine origin of law, it was felt that crimes were not so much offences against men, $i$. e., the state, as against the gods who protected man. ${ }^{35}$ In the Platonic theory the laws of earth had their archetypes in the other world. Thus the personified Laws sit at the bedside of the imprisoned Socrates and speak to him of their "own brothers, the laws in Hades." so Sophocles makes Antigone, in her clash with Creon, while asserting that the rights of conscience are above those of human law, say that "the laws were set among men by Justice, who dwells with the gods below," and that "their life is not of today or yesterday, but from all time, and no man knows when they were first put forth." 3 ?

The Greek idea of homicide, which developed after Homer's

"The Greek View of Life, Ch. II. Sec. 3.

IV, 4, 12 sq.

* On the religious character of Greek law, see Fustel de Coulanges, Le Cité Antique, III, ch. XI. He points out that the early laws of both Greece and Rome were mere religious codes, collections of rites, liturgical directions, prayers, etc. Thus the leges regiae of Rome had to do as much with religions as civil enactments; in the leges XII tabularum there were minute directions about the religious rites of sepulture. Solon's laws at Athens were at once $a$ code, a constitution and a ritual pertaining to sacrifices, etc.

- Crito, 54 C. .

"Antigone, 45I-452 and 456-457. (Jebb's Translation.) 
time, ${ }^{38}$ was based on the idea that where a murder had been committed, not only was it a crime against the gods and men, but that also a pollution had been brought upon the community; and inasmuch as the moral equilibrium had thus been disturbed, it could not be righted until the defilement had been removed from the state by the proper punishment of the murderer, who, by his act, had caused it. The causation of the pollution was, as we shall see later, extended to animals and lifeless things as well as to humans. It made no difference what kind of agency had caused the pollution; the main thing was to find the agency and punish it. Thus all through antiquity murder trials were held in the open air, in order that, as Antiphon says, ${ }^{39}$ the judges might not be contaminated by sitting under the same roof with one accused of crime. Thus the pollution was looked upon as physical as well as moral. This conception of homicide, according to which the murderer was a polluted person in the sight of God and man and could spread the pollution 40 among his fellow men, was never lost sight of. By his act the murderer had become impure and this disqualified him from communing with the Gods. ${ }^{11}$ The tainting of a temple or altar would cut off others from such communion, by bringing uncleanness to the very places to which men resorted when in quest of cleansing. The prosecutor at the funeral of the slain man, there-

In the poems of Homer, if the murderer remained instead of fleeing, there was no idea that his presence brought a pollution on the land: thus Orestes, in the Odysscy, I, $298 \mathrm{sg}$., needed no purification for his premeditated slaying of Aegisthus.

- V. II ; cf. Aristotle, Constitution, 57, 4. Thus homicide trials were held epi töi Palladioi ("at the Palladium"), epi toi Delphinisi ("at the Delphinium"), etc., as we see from Aristotle, op. cit., 57, 3; Demosth., 23, 7 I and 74, and 76, ctc.; Pausanias, in one passage, 1,28 , 10, says to d"ent Prytaneioi ("the court in the Prytaneum"), though he uses the preposition epi of the other courts, a difference probably without significance. Similarly the ancient Germans held their courts in the open air; see Grimm, Deutsche Rechtsaltertiumer (ed. Heusler und Hübner, I899), pp. 793 sq.

"Miasma or agos; the first properly means "stain or defilement" (cf. Lat. piaculum), and is used by Aeschylus, in the Eumenides, 169 and 281 ; Agamemnon, 1645; Septem, 682; by Sophocles, in the Oedipus Tyrannus, 97 and Ior2: by Euripides, in the Hippias, 35. The second term means "curse" or "pollution," and is so used by Sophocles in the Antigone, 256: by Aristotle, in the Politics, 5, 3, I: by Thucydides, 1, 126: in this passage Thucydides calls the polluted hoi enageis.

"In the Antigone, ro44, Creon rightly says "no man can pollute the gods," i. e., the pollution only extended to earthly agents. 
fore, uttered a solemn denunciation, in which the murderer was warned to keep away from all public places, sanctuaries, assemblies, agoras, etc. $^{42}$ The same denunciation was repeated in the agora by the King-archon. ${ }^{43}$ The pollution continued until the manslayer had expiated his crime by the proper ceremonies or by death. ${ }^{44}$ The pollution might keep up for centuries, where the state rather than an individual was primarily concerned. Thus at the outbreak of the Peloponnesian war in $43 \mathrm{I} \mathrm{B}$. C., the Spartans sent ambassadors to Athens demanding that the Athenians "drive out the pollution of the goddess." This referred to the slaying of the fellow conspirators of Cylon, during his rebellion nearly two hundred years before, after they had accepted the promise of safety at the altar of the Eumenides. ${ }^{45}$ If the murderer ran away and returned later and was seen walking in the proscribed places, the public prosecutor could carry him off to prison, where he must remain until he was tried again. ${ }^{48}$ He was safe from molestation so long as he stayed away and whoever, under these circumstances, slew him, was himself treated as a murderer. ${ }^{47}$

Because of the religious origin and character of homicide laws, they, like everything else connected with Greek religion, changed but little in course of time. The vitality of the idea

- See Demosth. 20, 158: cf. 23, 37; Antiphon, VI, 4: cf. V. 10; Sophocles, Oed. Tyr. 236 sq., where the denunciation of Laius murderers put into the mouth of Oedipus by the poet was borrowed from Attic law. Plato, Laws, IX, 87I A, says that if the kindred fail to prosecute, they also become involved in the pollution, and become hateful to the gods.

Aristotle, Constit., 57, 2 and 4.

H In the Eunrenides of Aeschylus, 230-231, the chorus of Furies threatens to pursue Orestes to death: again, in $421-423$, they say they will hound him to "where to rejoice not is the appointed doom."

w The conspiracy of Cylon (612? B. C.), is described by Herodotus,. V, 71. Thucydides, I, 126; Plutarch, Solon, 12 and 19. The archon Megacles (of the clan of the Alcmaeonidae) promised to spare the conspirators if they would leave the altar where they had sought refuge, but slew them instead. The clan was tried and banished in 596 or 595 B. C. at the instigation of Solon, but it returned later. The descendants of the guards who slew the conspirators were still in the city in $431 \mathrm{~B}$. C. At the same time the Athenians sent ambassadors to Sparta ordering the Spartans to drive out the "pollution of Taenarus." This referred to the slaying of certain helots some time before, who had taken refuge in Poseidon's Temple at Tacnarum; see Thuyd., I, 128.

- Demosth., 23, 80: law, 23, 28.

"Demosth., 23, 37. 
that they should remain constant is attested by the fact that Plato, in the fourth century B. C., still insisted that it was merely the state's business to regulate the methods by which vengeance should be meted out and to prescribe on what conditions the offender should receive forgiveness and become purified." Though changes occurred in other laws, in one domain, that of homicide laws, the $\Lambda$ thenians were singularly conservative in preserving them intact and inviolate. ${ }^{48}$ The criminal laws at Athens, as elsewhere in the ancient world, formed the most important part of the whole body of law.so While the rest of the legislation of Draco, the first Athenian to draw up a code of laws, was changed or abrogated a few years later by Solon in - the interests of less severity, ${ }^{51}$ its distinctive part, the laws governing homicide, not only was left unchanged by Solon, but under the democracy instituted after the fall of the Four Hundred in $4 \mathrm{II}$ B. C., and still later, in the time of Aristotle ${ }^{\mathrm{S}}$

- Laws, IX, especially $872-873$ : in $875 \mathrm{~A}$, he says that man must have laws and conform to them or his life would be as evil as that of savage beasts: he says this is because no man knows by nature what is best for the social state of man, or, if he did know, would he be able to do what was best, for "the true art of politics is concerned, not with private but with public good: for public good binds together states, but private only distracts them."

"Demosth., 23, 62, in speaking of Draco's laws, says that whoever, magistrate or citizen, should cause them to be "defeated" or "altered," shall with his children be disfranchised and his property shall be confiscated. Plutarch, Solon, 12, says of Solon's laws that each one of the thesmothetae swore at the stone in the agora, that if he broke any of them, he would dedicate at Delphi a golden statue as large as himself.

* Sir Henry Maine, Ancient Law ( 1883 ), p. 367, emphasizes the preponderance of criminal over civil law in all ancient codes. Thus in the Germanic codes civil law has trifling proportions in comparison with criminal. The sanguinary penalties of Draco's laws indicate the same character. Only in the leges XII tabularum at Rome, "produced by a society of greater legal genius and at first of gentler manners, the civil law has something like its modern precedence." He sums the matter up by affirming "that the more archaic the code, the fuller and minuter is its penal legislation."

"So Aristotle, Constit., 7, I: Plutarch, Solon, 17, states that Solon repealed all Draco's laws, except those concerning homicide, because they were too severe and the penaities too great: $c f$. also Aelian, Varia Historia,
VIII, ro.

"Aristotie, Constit., 4, I, gives Draco's activity as the year of the Archonship of Aristaechmus, Olympiad 39 (624-I B. C.); cf., also, Tatian, Adv. Graecos, $4 \mathrm{I}$; Clement of Alexahdria. Stromata, $\mathrm{I}, 366$; Suidas, Lexicon, s. v. Drakon, etc. Andocides, De Myst., 81 (cf. 83), says Diraco's laws were called thesmoi, while Solon's were called nomoi. Aristotle, however, called Draco's enactments thesmoi in one part of the Constitufion, 7,1 , and nomoi in another, 4I, 2. 
and Demosthenes ${ }^{58}$-three hundred jears after Draco's codification-was still venerated, thus escaping the encroachments of the popular (heliastic) courts. A study of Athenian homicide procedure, then, is almost entirely a study of the old code of Draco.

The laws of Draco, like the later ones of Solon, ${ }^{54}$ were probably originally engraved either on triangular tablets fitted together at the angles so as to form three sided pyramids known as kyrbcis, ${ }^{55}$ or on revolving wooden pillars faced with rectangular tablets called a.voncs, (axles). ${ }^{50}$ In all probability these tablets stood in the Royal Stoa. ${ }^{57}$ Later, in the years $409-408$ B. C. ${ }^{57 \mathrm{a}}$ by a plebiscite vote these laws were engraved upon a stele which was placed in front of the King's Stoa, where everyone could read and copy them for his own purpose. This plebiscite was one of the measures which followed the overthrow of the oligarchy of the Four Hundred in $4 \mathrm{II}$ B. C., which was in theory followed by the Five Thousand, but actually by all who were able to equip themselves for service in the heavy armed infantry. ${ }^{58}$ In the year $410 \mathrm{~B}$. C., in consequence of the sea victory of Alcibiades off Cyzicus, the Athenians were encouraged again to establish the democracy. This change was accompanied by great legislative activity. ${ }^{50}$ A board of recorders

47, 71 : cf. also, Andocides, De Myst., 82 and 83.

"Cratinus, apud Plutarch, Solon, 25, says both Solon's and Draco's laws were engraved on kyrbeis.

"They were first mentioned by Cratinus, $l$. c.; cf. Plato, Politicus, 298 D: Lysias, 30, 17 and 18: Aristophanes, Fragm., 352. Plutarch, l. c., says these tablets were of wood, while the scholiast on Aristophianes, Aves, 1354, says they were of brass and Apollodorus, apud Suidas, s. v. kyrbeis, of stone.

* Plutarch, 1. c.; Eratosthenes, ap. Schol. on Appius Rhodius, IV, 280. Plutarch adds that relics of them were to be seen in his day (second century, A. D.), in the Prytaneum, and he identifies axones and kyrbeis, though he also gives the variant opinion that the latter were used for ceremonial and religious laws, and the former for civil; cf. also Etymologicum Magnüm, s. v. axoncs. On both, see Busolt, Griechische Staats- und Rechisaltertïmer; ed. 2, p. 153 sq.; cf. his Gricchische Geschichte, II, and ed., 290, n. 3 .

${ }^{\prime \prime}$ Aristotle, Constit., 7, I, says Solon's kyrbeis stood here: ef. Harpocration, s. v. kyrbeis. On the King's porch or stoa, see Botsford, Hellenic History, ch. XIII.

re This is the date of the archonship of Diocles.

" See Thucydides, VIII, 97: cf. Botsford, Hellenic History, ch. XIX.

- A portion of this activity was concerned with the passage of a decree limiting the power of the Council of Five Hundred, determining its relation 
(anagraphcis) was appointed to remove inconsistencies from the old code of Draco and to reëngrave the separate statutes. This board continued in office for six years and abused its trust. ${ }^{\circ 0}$ This revision was interrupted by the calamities which befell Athens at the end of the Peloponnesian War, but was revived after the Thirty Tyrants had been expelled and the old democracy had been again restored under Thrasybulus in 403 B. C. ${ }^{61}$ Fortunatcly we still possess a portion of this revision on an inscribed stele."2 The text is in a fragmentary condition and can be restored only in part (the last ten lines being quite illegible) with the help of Demosthenes, ${ }^{03}$ the Constitution of Athens by Aristotle, ${ }^{04}$ and hints from various other sources. ${ }^{65}$ It should be added that the details of Attic law depended very largely until recent years on $e \cdot x$ parte statements in certain of the orators, specially Demosthenes, Lysias and Antiphon, ${ }^{86}$ which, in some cases could be checked by inscriptional evidence. In modern texts of the orators, the places where the speaker stopped to

to the assembly and, perhaps, to the heliastic courts: see Corpus Inscriptionum Graecarum, I, 57, in connection with Aristotle, Constit., 45.

"So Lysias, 30, init: Commissioners (syggraphcis) had already been appointed in 450 B. C., and again in $446 \mathrm{~B}$. C., with absolute powers to compile the laws to be laid before the people. "Thucydicles, VIII, 67 (cf. Isocrates, 151 D), uses this term in March, 4II B. C., but in the following October, just after the Four Hundred had been overthrown, he calls them "omothetai, VIII, 97. The anagrapheis were scribes or secretaries, who received the laws from the king-archon and set them up at the Royal Stoa.

"Andocides, De Myst., 83; cf. Schol. on Aeschines, 1, 39 .

at is to be found in Corpus Inscriptionum Atticarum $(=$ C. I. A.), 1, 61 (Kirchhoff, 1873; Suppl: to Vol. I, 1877, p. 18); Hicks and Hill, Greek Historical Inscriptions, 78: Dittenberger, Sylloge, and ed., I, . 52; Macartatus).

"Especially ch. 57.

she inscription was first restored by Köhler, in Hermes, II (1868), pp. 27 sq.; by 'Philippi, Jahrbuch fiir Philologic, CV, pp. 577 sq. (cf. Dir Arcopag und die Epheten (1874), pp. 333 sq.); best of all text, translation and commentary-by Dareste, Haussoulier et Reinach, in the Recucil des irsscrip. tions juridicques grecques, II, I-24 On the code of Draco and the revision of 409-408 B: C., see E. Meyer, Geschichte des Altertums, II, 573-579; Busolt, Griech, Gesch, II (2nd ed.), pp. 225-243; III, 1538; n. 3: Gilbett, Beiträge zir Entrevickelungsgeschichte des griechischen Gerichtsverfahrens, in Jahrbuch fiir Philologie, Suppl Bd. XXIII (I897), pp. 443-536; Botsford, The Development of the Athenian Constitution, pp. 146 sq., and Hellenic Civilization. (Botsford and Sihler, 1915), pp. 288 sq.

Of Antiphon we have only logoi phorikoi left; of Isaeus, on the other hand only logoi klêrikoi. 
let legal extracts be read in court a're inarked nomoi (laws). At the completion of the trial the speech would be kept by the person for whom it had been written for use in possible future litigation; consequently the speech would becone separated from the legal extracts, the latter being onitted when the former was kept for its literary merit only. The fragnients of law inserted in the manuscripts and copied over in our texts are either the constructions of later hands taken from the context of the speech itself and hence are generally inaccurate, of in some way they were copied from the actual laws, inasmuch as they correspond with known inscriptions exactly: ${ }^{B 7}$

The various Athenian courts of homicide are not mentioned in the Draconian inscription, but their names are known to us from Aristotle, Demosthenes and other sources. ${ }^{88}$ From these writers we learn that down to the second century $A . D$. there were five different homicide courts at Athens-the Areopagus, Palladium, Delphinium, Phreatto and Prytaneum. The Draconian inscription also, strangely enough, does not contain the article on murder in the first degree-the trials of which took place at the Areopagus court-and we are dependent for our information about it on other sources. ${ }^{60}$ Our next task will be

" See Gardner and Jevons, Mantual of Greek Antiquilies (i\&95), pp. 527-528. Since the discovery of Aristotle's work on the Constitution of Athens, which treats largely of the jurisdiction of public officials and court machinery, we can dispense almost entirely with the testimony of lexicographers and scholiasts, whose information we now know goes back to that work.

- Const., 57, 3; Demosth., 23, 65-79; Pausanias, I, 28, 5-I, 8, ir ; Pollux, Onomisticon, VIII, II7-120: Pausanias gives the fullest account of these courts; since they were, however, unimportant for a traveler to visit and were widely separated-from the north slope of the Acropolis to the Piraeus-most' scholars believe that his account has no.topographical value, but is merely an antiquarian excirsus: see Schubart, Jahrbuch für Philologie, XCVII, 825 sq.: Wachsmuth, Rheinisches Museum, XXIV, 36, and Die Stadt Athen, 1,132 ; Hagemann, De Prytaneo, p. 28, n. 46. Others, however, c. g. Curtius, Die Staatsgeschichte Athests, p. 289, believe that Pausanias actually visited them and that they would be of interest to Roman travelers for whom he wrote, inasmuch as the Romans looked on Athens as the fountain head of their law ( $c f$. Aelian, Var. Hist., VIII, 38), and because they, on taking over Greece, raised the Areopagus, the most important of these courts, to great honor again.

- Just why it is omitted from Draco's tablet cannof be definitely settled. The most satisfactory explanation is to assume that Solon, in his revision of Draco's murder code, abolished that article and substituted one of his own. This would account for the fact that Draco nowhere in his legislation mentions the Areopagites but only mentions Ephetai, who, as we 
to discuss as bricfly as possible these five courts, their competence, agre and management. Before doing so it will be well to review the procedure followed in murder trials at Athens, which, with trifling differences, seems to have been the same in all five courts. We know this procedure from statements of various writers, especially the orators. It is very simple and direct. The first thing to do was to lay the indictment (graphe phonou). This was done by the relative of the slain man within the usual degree of cousins' children inclusive. ${ }^{\text {To }}$ lior, as we have seen, the nearest of hin was bound from the earliest days by religious sanction to be the avenger of blood guilt. The judicial summons (prosclēsis), ${ }^{i 1}$ that the murderer appear before the King-archon ${ }^{72}$ and answer the charge, was made by the kinsman before witnesses. The prosecutor uttered at the funeral of the slain man the solemn denunciation already mentioned (technically called prorrhēsis), warning the murderer to keep away from public places, sanctuaries, assemblies, etc. ${ }^{73}$ This interdict was repeated by the King-archon in the market place. ${ }^{74}$ Three successive investigations in three successive months were made by the King-archon ${ }^{75}$ and the case was brought to trial

shall see, had the management of the Palladium, Delphinium and Phreatto; cf. also, Plutarch, Solon, 19. Plutarch's words show that he probably only saw the restoration of $409-408 \mathrm{~B}$. C., and not the original Draconian tablet: see Hellenic Civilization, pp. 288-289. It may be added that the word $K a$ i (and), which begins the first law on the Draconian stele, shows that something preceded-either the clause about wilful murder inserted by Solon or the original one of Draco. The stele is superscribed as protos achson (= protos axdn): whether this means the "first axle" of Solon's or Draco's code cannot be determined. stele).

"Demosth., 47, 72: law, 43, 57: C. I. A., I, 6I, line 17 (the Draconian

${ }^{7}$ Demosth., 43, 15: Lysias, 6, 11 : Aristophanes, Vespae, 1041: cf. Plato, Laws, VIII, $846 \mathrm{~B}$, and IX, $855 \mathrm{D}$.

Aristotle, Constit., 57, 3 .

"Antiphon, V, 88; VI, 6: Demosth., 47, 69: Plato, Laws, 1X. 871 C, 87.3 A: cf. C. I. A., I, 6r; line 17 sq. Those who met a violent death at Athens were interred with peculiar formalities. We learn from several writers-c. g. Demosth., ibid., Euripides, Troades, 1148: Harpocration, s. $v$. epenegkein doru-that to symbolize the pursuit of the murderer, the accuser carried a spear in front of the funeral procession and, after making the proclamation at the tomb, stuck it upright on the grave and watched it for three days.

"Aristotle, Constit., 57, 2 and 4; cf. Bekker," Anecdota graeca; 3to, 6-9; Plato, Laws, IX, 874 A.

"Antiphon, VI, 42 
on the last three days of the fourth. ${ }^{70}$ The King-archon, after examining the case, assigned it to the proper court and in all cases presided at the trial. ${ }^{7}$ The plaintiff and the defendant were each allowed to speak twice. ${ }^{78}$ After the accused had delivered his first speech, he had the right (unless a parricide ${ }^{79}$ ) to go into voluntary exile and thus not run the risk of being condenmed, neither the plaintiff, nor the judges having the power to restrain him. ${ }^{80}$ If he returned, the victim's kinsmen could slay him or hale him again into court, though they were not allowed to maltreat him. ${ }^{81}$ If he did not avail himself of the permission to flee, but stood his trial and was condemned, he had to stand the sentence of the court. If the plaintiff, howcver, got less than one-fifth of the votes of the judges, he was mulcted in a thousand drachmae. ${ }^{82}$ If the accused was condemned to death, his person was given over to the proper officials. ${ }^{83}$ The accuser had the right to see the guilty man suffer the death penalty, a right which appears to have been a relic of the old blood vengeance. ${ }^{84}$ However, even after conviction, the defendant could still be forgiven and released by the kinsman of his victim. Again if the murdered man, just before dying, forgave his slayer, the latter's kinsmen could not prosecute. ${ }^{85}$ This seems to be a remnant of the Homeric custom of pardoning a murderer when zucrgcld had been paid. ${ }^{86}$ Such, in brief, was the procedure in all murder trials in Athens.

"Pollux, VIII, 117: Antiphon, ibid., says that the last three months of the Attic year were excluded for trying homicide cases because the archon was not allowed to hand them over to his successor. 6 sq.

"Aristotle, Constit., 57, 4: cf. 56, 6 and 57, 2; Bekker, Anecd. gr. 310,

Pollux, VIII, II7.

"Pollux, VIII, I17: cf, VIII, 99.

"Demosth, 23, 69: Antiphon, V, 13.

"Demosth., 23, 28: cf. Plato, Laws, IX, 871 D.

- Demosth., 23, 80.

"Demosth, 23, 69.

"Demosth., 23, 69

"Demosth., 37, 59 .

* It might be added that in Maina, the rocky district of Mt. Taygetus, southwest of Sparta, murder is still, as it was in Homeric days, a private affair between man and man. Feuds have always been common there. 
From Draco's day, if not earlier, ${ }^{87}$ Attic law distinguished between three kinds of homicide, roughly corresponding to three courts: premeditated murder (phonos hekousios or ck pronoias), tried at the Areopagus: unpremeditated murder (phonos akousios), tried at the Palladium; justifiable murder (phonos dikaios), tricd at the Delphinium. In practice no middle ground between the first two was recognized. Such a distinction is found only in the Platonic theory, according to which slaying in anger is rccognized, as also different penalties according to whether the deed is committed in passion, with intention urged on by feelings. of revenge, or without premeditation. ${ }^{88}$ In general it must also be said that Athenian laws governing homicide, though precise, were far from scientific. Distinctions between various degrees of guilt in different sets of circumstances were drawn and consequently, as Jebb has said, "depended rather on minute tradition than on clear principle." A captious or even frivolous style of argument was invited by a code which employed vague conceptions in the elaborate classification of accidental details. ${ }^{82}$.

Cases of premeditated murder were considered by the Athenians as by us to be the worst offences known to the law ${ }^{00}$ and

"Leist. Graeco-Italische Rechtsgeschichte (I884), wrongly assumes that there was a distinction between premeditated and unpremeditated murder cven in Homeric times. Lipsius, Das Attische Recht und Rechisverfahren [based on Meier-Schömann's Der Attische Prozess (1881-1886)], I, p. 19, easily confutes this. A good example of premeditated murder is found in the Odj'ssey. XIII. 259 sq., where Achilles tells the disguised Athena that he is outlawed for having slain Orsilochus. An example of unpremeditated murder is found in the Iliad, XXIII, 85 sq., where the wraith of Patrochus recalls to Achilles how he once killed a playmate at dice in childish wrath, though "not willing it." The acceptance of wergeld on outlawry was, as we have seen, the same penalty in both cases.

- Laws, IX, 866 D, sq. Here Plato says a deed is done from passion when men, suddenly and without intent to slay, kill on momentary impulse and become repentant immediately thereafter. or from feelings of revenge when a man is slain and no remorse is felt: "And therefore we must assume that there are two kinds of homicide. both of them arising from passion, which may be justly said to be a mean between the voluntary and the involuntary."

- Attic Orators (1893), I, p. 45. Though other kinds of evidence were admitted, the legal contest largely turned on general probabilities (eikota) and so quite differently than in modern courts. The ability of the orator, the ingenuity with which he could invert the facts, helped then more than they do now.

- Antiphon, V, 10, says this is the worst $\sin$, comparable with sacrilege (temple plunder) and treason. 
were tried exclusively at the court of the Areopagus. ${ }^{\text {D1 }}$ This was the oldest and most sacred of the Athenian courts. ${ }^{02}$ It was held like the other courts in the open air ${ }^{93}$ on the top of the bare rocky hill just west of the Acropolis. ${ }^{94}$ The court was held in the day time and not at night as has been generally assumed." Athenian law recognized three kinds of voluntary homicide, where death was brought about by wounding, poisoning and arson." In each case intention (pronoia) seems to have been essential. ${ }^{\text {7 }}$ At the trial the plaintiff and defendant had.

"Aristotle, Constit., 57, 3: Demosth. 20, 15\%, efc. The Areopagus was called $\bar{c}$ boule $\bar{e}$ cx Arciou pagon or Arció pagdi or simply $\bar{e}$ baule. The form Arciopagos is found only in late inscriptions. The ancients mostly connected the name with the god Ares, who was said to have been the first to be tried on the Areopagus for the murder of Halirothius; Paus., I, 28, 5: Apollodorus, III, I4, 2: cf. Demosth. 23, 66: Euripides, Electra, I258 sq.; Hellanicus, frag. 69 (ed. Müller), taken from Euripides. Others explained the name from the myth that the Amazons, servants of Ares, sacrificed here to the god while they were beleaguering the Acropolis: Aeschylus, Eumenides, $685 \mathrm{sq}$. Most modern scholars, however, derive the name from the altar of Ares at the northeast foot of the hill: Wachsmuth, Die Stadt Athen, I, p. 428, n. 2; but Pauly-Wissowa, Realencyclopädic, II, 227, s. $v$. derives the name from Athena areia, who had a sanctuary on the hill. Gilbert, Handbuch der griechischen Staatsaltertümer, II (2nd ed.), p. 425, n, 4, derives it from ara (curse), referring to the cave sanctuary of the Erinyes at the foot of the hill; the Erinyes are called arai (curses) by Aeschylus, Eumenides, 417 , and this was the place where men made offerings and swore oaths: see Pausanias, I, 28, 6. This derivation derives support from the fact that solemn oaths were sworn to the Furies and other deities upon this hill and that a man who there forswore himself was supposed to have incurred "all curses of the city": Deinarchus, I, 46: cf. Philippi, Der Areopog und die Epheten, p. 8 sq.

Demosth., 23, 65; cf. Antiphon, VI; 2 and 4

Antiphon V, II : Pollux, VIII, Ir8.

"Herodotus, VIII, 52; Lucian, Bis accusatius, 12, and Piscat., 42; Schol. on Clemens Alexandrinus, Protrepticon, 3, 3, 4; if. Bekker, Anced. gr. I, 253, 27. It was held on the plateau at the eastern end, which is hewn in the rock behind an altar-like block approached by fourteen steps from the south; see Curtius, Atlas, Bl. IX, 2: Wachsmuth, Die Stadt Athen, I, 25, I: Milchhöfer in Baumeister, Denkmäler des klassischen Alterthums, I, p. 200 (Article Athen).

"Lucian, Hermot, 64, and De dosino, 18.

* Aristotle, Constit. 57, 3: Pollux, VIII, 117: Demosth. 23, 24, and law 23,22 . On the subject of irauma $c k$ pronoias, pyrkaia, pharmaka, see Gleue, De homicidarum in Areopago Athenicusi iudicio (Göttingen, 1894), pp. 23 sq.: and Gilbert, Handbuch, II, 426, n. 2.

"Aristotle, Constit. 57, 3: Ethics, I, 16, I 188, n. 31 (an example where a woman was freed when no intention at poisoning could be proved). In law "intention" was not only to wound, etc., but to kill;' see Lysias, 3, 40-43. Lysias' Oration 4, "On Wounding with Intent," is an example of such a case. If intention were not proven, the case was one of hybris (outrage or aggravated personal assault): Demosth. 54,$24 ; c f .21,34$; or aikia (assault or affront), which was of a lighter degree and easier to sustain: Demosth. 2I, 
to stand upon two rough white stones, one of which was called "Ruthlessness" (lithos anaideias) and the other "Insolence" (lithos hybreos), "18 where they took a most solemn oath, each imprecating himself, family and kin. ${ }^{99}$ The penalty, in order to give full satisfaction to the ancient blood-revenge, was the severest--death and confiscation of property or exile. ${ }^{100}$ Only in the case of a tie vote was an acquittal possible. ${ }^{101}$ The penalty seems to have been regarded as more ethical than juridical in principle, for throughout antiquity the sentence of the Areopagites was considered to be the expression of the most solemn truth and justice. ${ }^{102}$ In cases of intentional wounding, where death

34-35. A good example of the latter is afforded by Isocrates, Orat. 20 (Against Lochites); here Isocrates calls the offence complained of both hybris (Secs. 2, 7, 9, 16), and aikia (Secs. 5, 15); also Demosth., Orat. 54 (Against Conon); in this speech Demosthenes, like Isocrates, is dealing with aikia, but also calls it hybris (Secs. 1, I1, 17) : both orators thus seek to combins the forces of two distinct forms of accusation. Cases of aikia were not confined to the person injured; any citizen cognizant of the assault, could lay the indictment before the thesmothetae.

- Pausanias, I, 28, 5.

" This oath is given by Demosth. 23, 67-68; "it is no ordinary oath . . . but one that no person swears in any other matter; he must stand on the entrails of a boar, ram and bull slain by the proper person at the proper time . to meet the requirement of religious law." $C f$. Antiphon, V, ir. Similar oaths, though not under such impressive circumstances, were sworn at other times: thus Piso, in Lysias, Orat. 12, 10, swears one to Lysias, imprecating destruction on himself and family.

${ }_{200}$ Demosth. 21, 43: cf. Lysias, 3, 38; Antiphon, V, 10: Aristotie, Cotstit. 47, 2. Meier's idea (De bonis dammatirum, p. 18; cf. Meier-Schömann, Der Attische Process, ed. I, p. 308 ), that confiscation only took place if the defendant escaped the death penalty by flight after his first defence speech, was shown to be Ifalse by Philippi, Der Areopag und die Epheter, p. Iog: of. also Thonissen, Le droit penal, 24 Since the discovery of Aristotle's Constitution we know that he did not use, in ch. 47,2 , the words to that effect which appear in Pollux, VIII, 99: cf. Lipsius, Das Attische Recht und Rechtsverfahren, II ( 1908$)$, p. 603 . Examples of intentional murder are plentiful; c. $g$. Antiphon's First Tetralogy and Third Tetralogy, and Lysias' great oration, n. 12, Against Eratosthenes. Eratosthenes was probably, however, not prosecuted under an ordinary indictment for murder, but was probably accused on the occasion of his coming forward to render an account of his office as one of the thirty tyrants: see Blass, Die Attische Beredsamkcit von Georgias bis $z$ ul Lysias ( 1868 ), pp. $540-541$ : the result of this trial is unknown, but probably the accused, for political reasons, was not put to death.

${ }^{102}$ Aeschylus, Eumenides, 735: Antiphon, V, 51: Aeschines, 3, 252

${ }^{102}$ Cf. Lycurgus, Orat. 12: Aristeid., Orat. 13, p. 171: Demosth., 23, 67; the latter says that only at the Areopagus "has it occurred that neither a convicted criminal nor a defeated prosecutor ever established a charge against the propriety of the verdict." On the wisdom of the court see also Sophocles, Oedipus Colonets, 947 sq. (which passage Demosthenes may have had in mind in the above statement) ; Cicero, Epist at Atticum, I, I4, who, in praising the conduct of the Roman Senate, says: "Senatus areios pagos: nihil consfantius, nihil severius, wihil fortius." 
did not follow, the death penalty was exile and confiscation of property. ${ }^{103}$ In cases of poisoning ${ }^{104}$ there was no suit unless death followed. The cause of death was assumed from the circumstances, as there were no autopsies by physicians in antiquity. If the case were proven, death was the penalty. ${ }^{103}$

Only cases of wilful murder against Athenian citizens were tried before the Areopagus. Similar cases against resident aliens, strangers and slaves were tried at the Palladium. ${ }^{100}$ The penalty inflicted was.exile. ${ }^{107}$ However, the main function of the Palladium was the trial of cases of involuntary homicide (pironoi

${ }^{100}$ Lysias, 3, 47: 4, 18: of. 19, 38: Demosth. 40, 32; Pseudo-Lysias, In Andoc. 6, 15. Lysias, Orat. 3 (Defence against Sinron), is a good example; here an elderly Athenian was accused by Simon of having wounded him in 2 quarrel over a Plateaan, the indictment being traumatos ek pronoias. This sort of indictment was a notorious instrument of false accusation at Athens: cf. Demosth. 40, 32. Aeschines, In Ctesiph, charges Demosthenes with having brought a false charge of this sort against a certain Demomeles and says this is one of the habitual villainies: $c f$. also Lucian, Timon, 46.

so On pharmaka (later called pharmakeia, see Aelian, Timacus, s. v. with definition), see Philippi, Der Areopag und die Epheten, Pp. 113-I14 and 120. Antiphon's speech (n. 6), On the Choreutes, relates to the death of a boy named Diodetes, who, while being trained as a chorus singer for the Thargelia, was poisoned by a draught given to improve his voice (cf. Plutarch, De gloria Athen, 6, for the pains taken to train choral voices): the choregus was accused by the boy's brother. Jebb, Attic Orators, I, 61, n. 3, believes this case was tried before the Areopagus (in section 82 it is called "the most conscientious and upright" court in Greece). Another example is Antiphon, Orat. I (Against a Stepmother on a Charge of Poisoning), where the accuser, a son of the deceased, charges his stepmother with having poisoned his father years before by the instrumentality of a female slave, her dupe; at that time the slave was put to death; now the youth demands that the real criminal be punished.

${ }_{2 \infty}$ On the Areopagus see Paus. I, 28, 5 : Pollux, VIII, r17: Bekker, Anecd. gr., I, 253, 26 sq.: Philippi, op. cit., p. 23 sq.: Gilbert, Handbuch, I (2d Ed.), pp. 425-427, and notes: Lipsius, op. cit., I, pp. 121-129 II, pp. 603 sq. Ziehen, Die Drakontische Gesetzgebung, in the Rheinisches Musenm, N. F. liv (1899), pp. 321-344: Pauly-Wissowa, art. Areios pagos (by Wachsmuth and Thalheim), ap. cit., II, pp. 627-633: E. Caillemer, art. Areopagus, in Daremberg et Saglio, Dictionnaire des Antiquités grecques et romaines, I, (1873), pp. 395-404 However, all works published before the publication of Aristotie's Constitution in $189 \mathrm{I}$ are obsolete.

${ }^{30}$ To epi toi Palladioi dikasterion, held near the sanctuary of Pallas Athena, in which images of Athena and Zeus were worshipped: C. I. A., I, 273 (fragments of lines 5 and 22 ): III, 71 . This court was situated somewhere "east of Athens" (Plutarch, Theseus, 27), on the borders beiween Athens and Phalerum, as we learn from the concurrent testimony of Phanodemus (apud Suidam, s. $v$. eppi Palladioi), Pollux (VIII, II8 sq.), and the Schol. on Aeschines (II, 87, p. 298) : see Curtius, Karten von Attika, Erläuternder Text, I, 58. It later, like the Academy, became the haunt of philosophers; Plut. De exilio, I4.

in The punishment of metics (resident foreigners) is alone given; Bekker, Anecd. gr., I, 194, II. That of slaves can be deduced from Demosth., 23, 89, 
akousioi, mee ek pronoias) which the Athenians recognized as far less criminal than those of intentional slaying and consequently as meriting a lighter punishment-exile without confiscation. ${ }^{108}$ According to Demosthenes, the law ordained that persons banished for unpremeditated murder must leave the country-which had been made impure by the crime-by an appointed road within a certain time and remain in exile until he found forgiveness with the victim's kin, after which he might return if he performed certain sacrifices and purificatory ceremonies. ${ }^{108}$ Draco's tablet says that if anyone kills the murderer, who, on being convicted of accidental homicide, has gone into exile, or cause him to be slain while he is away, he shall be subject to the same penalties as one who has slain an Athenian. The exile can be killed only if he has returned; or he may be arrested and not be maltreated, nor can ransom be accepted under penalty of paying double the amount of damage incurred by the murderer. Aschines says that the victorious litigant in a case tried at the Palladium had to strengthen his declaration with an. oath. ${ }^{110}$ This oath is given by Demosthenes as an "imprecation on self and house." 111

and similar formulae in inscriptions: c. g., C. I. A. II, 115: IV, 1, 27 c: á, 33 b, If you owned the slave in question, religious payment was allowed: Antiphon, VI, 4. The punishment of foreigners (other than metics) was probably exile.

${ }^{200}$ C. I. A., I, 61, line II sq.: cf. Demosth., 23, 45, and 71-72; Aristotle, Constit., 57, 3; Pollux, VIII, I18; Bekker, Anecd. gr., 3I I, 3: Pausanias, I, 28, 8-9: Harpocration, Lexicon, s. $v$. epi Palladiōi (quoted from Aristotle, as are also the epitomes of the other lexicographers, Suidas, the author of the Etymologicum Magnum, etc. A good example of involuntary murder is afforded by Antiphon's 2nd Tetralogy, where a boy is represented as being killed by running in the way of a javelin hurled by a youth who was practicing javelin throwing at the gymnasium.

${ }^{100} 23,72$ : cf. Plato, Laws, IX, p. 877. On aidesis (forgiveness), see Demosth. 21, 43 ; the murderer must get it from the father, brother and sons of the victim, all agreeing; if one voted against it, none was given and the exile could not return; $C .1$. $A$. I, 6I, line 13 sq.: "[If there are no] such persons, the relatives as far as the degree of first cousin [may forgive, if all of theml are willing, after swearing the oath"; line 16 reads: "If there is not any of these persons and the homicide was involuntary and 51 ephetai decide that it was involuntary, the slayer shall be admitted to the country by ten members of the phratry, if they are willing. These persons shall be chosen by the $5 I$ from those of noble birth." Cf. this with Demosth. 43,57 . We learn from the Schol. B. on the Iliad, II, 665, that the man could return anyway after five years.

$$
\begin{aligned}
& { }^{210} 2,87 . \\
& 47,70
\end{aligned}
$$


One other kind of trial was held at this court-the crime of instigating murder, technically called boulcusis; for complaints were entered not only against actual agents, but against those who urged others on to commit murder, on the principle that qui facit per alium, facit per se, and consequently was morally responsible for the crime. ${ }^{172}$ It appears to have made little difference to the court whether death was intended or not. Gilbert has shown that these cases were added to the jurisdiction of the Palladium in the latter part of the fourth century B. C., having been previously tried at the Arcopagus. ${ }^{113}$ The penalty was the same as that for the actual commission of murder: thus, if death of the victim resulted, the punishment was death and confiscation of property just as in voluntary homicide decisions at the Areopagus: if death were intended but not effected, exile and confiscation of property, as in cases of wounding with intent to kill, where death did not follow, at the Areopagus : if instigation were proven in an act which caused death, though no intention to kill could be shown, the penalty was exile, as in the case of involuntary homicide at the Palladium. ${ }^{114}$

- Besides wilful murder Athenian Law also recognized certain cases of lawful homicide, $i$. e., where the accused could fully admit the crime as intentional and plead that he had a

${ }^{213}$ C. I. A., I, 61, fine 10: Andoc., De Myst., 94, p. 46. On "instigation," see the definition in Harpocration, s. $v$. bouleuseos; Forchheimer, De Areopago, p. 30, defined it as id crimen, quo quis, quacunque sit ratione, ipse tamen a necando manus abstinens, hontinem morti studeat dare. See also PaulyWissowa, Realencyclopädie, III, pp. 1037 sq.: Gleue, op. cit., pp. 39 sq.

${ }^{12 x}$ Jahrbuch für Philologie, Suppl. Bd. XXIII, pp. 524 sq.: cf. also Lipsius, op. cit., p. I29. This explains Harpocration's statement that according to Isaeus and Aristotle such cases were tried at the Palladium, but according to Deinarchus at the Areopagus-a discrepancy reconciled by the fact that "instigation" cases were transferred from the Areopagus in the fourth century. See Sauppe, Orat. Attic, II, 235; Wilamowitz, Aristoteles und Athen, I, 252, n. 138; Gilbert, Handbuch, I, 427, n. 3; cf. Philippi, Der Areopag und die Epheten, p. 29; Jebb, Attic Orators, I, p. 6I, n. 3. Antiphon's Orat., I (Against a Stepmother) furnishes a case of bouleusis with intent, while his Orat. VI (On the Choreutes) is one of bouleusis without intent; however, both of these cases were tried at the Areopagus before the transference mentioned took place.

"I" On thie Palladium, see Milchhöfer, article Athen, in Barmeister's Denkmäler, I, pp. 179 sq.: E. Curtius, Stadtgeschichte Athens, p. 55: Busolt, Griechische Staats- und Rechisaltertümer, Ed. 2, I, Sec. 207, p. 273 : Gilbert, Handbuch, I, (2d Ed.), pp. 427-428: Lipsius, op. cit., pp. 129, and 609 sq.: $c f$. p. 605. 
right to commit it. Such cases (phonoi dikaioi) were tried at the Delphinium." Demosthenes speaks of this court as "the most sacred and awesome" of all courts. ${ }^{110}$ The law took account of various legal murders-the slaying of adulterers, opponents in athletic contests, companions in battle, self-defence against thieves and highwaymen. ${ }^{117}$ No penalty was meted out if the case were proven. As for adultery Demosthenies says the criminal can be slain if he has committed the crime with wife, mother, sister, daughter, concubine, or free children. ${ }^{118}$ Solon added a law about thieving at night to the effect that it was lawful to kill or wound the thief if one were pursued or to hale him before the Eleven-at the option of the one concerned. ${ }^{110}$ Plato countenanced just murders, as when a thief is caught at night or a footpad is slain by a man in self-defence or violence is done

"To dikastirion to epi Delphiniōi, held at the temple of Apollo Delphinius and Artemis Delphinia; $C$. I. A., III, 932: cf. Pausanias, 1, 19, $x$. Its exact location is conjectural, but it must have lain somewhere east of the Olympieum, i. e., not far from the Aphrodite in the Gardens; see Milchhöfer, Baumeister's Denkmöler, 1, p. 179: Wachsmuth, Jeno Litter. Zeitung (1875), XI, VII, p. 829. E Maas, De Lenaeo et Delphinio commentatio, Greifswald, 189I, p. xvi sq., wrongly identified it with the temple of Apollo patroios in the agora. On the myths of the origin of this court, see Pausanias, I, 28, 10; Pollux, VIII, II9: Schol. Patm. on Demosth., 23, 74: Bekker, Anecd. gr. I, 255, 19: Etymolog. Magn. 358, 57. Cf. Philippi, Der Areopag und die Ephetcn, pp. I5-16.

23, 74

${ }^{319}$ Aristotle, Constit. 57, 3 (adultery, athletic contests and war) : Demosth. law, 23, 55 (adultery, athletic contests, war and highwaymen): cf. 23,60 , where he says if anvone in self-defense shall slay a man who is unlawfully thieving, his death shall be unpunished; this is almost word for word the statement in Draco's tablet, line 37 sq. Plato; Laws, IX, 865 A, B, mentions athletic contests, military exercises and war; he also mentions deaths at the hands of physicians, unintentional slaying with one's own hand unarmed or with a dart; death caused by-food, drink, application of cold and fire, suffocation whether by oneself or through the agency of another, Harpocration, s. v. epi Delphisioi, quotes from Demosthenes, 23, 53; and Aristotle is epitomized by Suidas and the author of the Etymolog. Magnum, s. v. hodos. Cf. also Plutarch, Thesers, 18; Pollux, VIII, Ir9; Pausanias, I, 28 , 10.

141 23, 53: Pausanias, IX, 36, 8, says Draco legislated no penalty for slaying adulterers. An example of adultery is found in the first oration of Lysias (On the Death of Erastosthenes), in which Eratosthenes pas slain by a humble citizen who found him in bed with his wife and the murderer pleaded justifiable homicide. The case was tried at the Delphinium hefore heliastic jurors-who replaced the ephefai probably at the end of the fifth century. See Isocrates Adv. Callitin, 54.

is Demosth., 24, 113. 
a free woman or youth or in case of adultery or when one defends himself from his father, mother, children, wife or brothers. ${ }^{120}$

Besides these great courts of homicide there were twoothers for the trial of less usual and less important cases, the Phreatto and the Prytaneum. At the former on the shores of the Piraeus, ${ }^{121}$ those were tried who had been banished for involuntary homicide and were not yet pardoned by the kinsmen of their victim, and were accused anew of a voluntary homicide. ${ }^{122}$ The criminal had to return to the Piraeus and plead his case from a ship while the judges sat on the shore. ${ }^{123}$ If he were found guilty of the new accusation, he was condemned to death; if acquitted, he had to return into exile because of his former crime. ${ }^{124}$

20. Laws, IX, 874 B. In $869 \mathrm{C}$, he gives no penalty where a brother slays a brother in 2 broil, if the slain man began it; or if a citizen slay a stranger under such conditions or vice versa. On the Delphinium, see Philippi, Der Arcopag und Epheten, pp. 55 sq.: Gilbert, Handbuch, I, 428 sq.: Lipsius, Das attische Recht und Rechtsverfahren, pp. 130 and 614 sq., etc.

"2n To dikastērion to els Phreattoi. Demosthenes uses the name only in the dative (en Phreattoi, 23, 76 and 78 , though we find en Phreaitou in Codex $\Sigma$ ), as does Aristotle, Politics, $L V, 13,2$, p. 1300 b 29; this dative yields a nominative Plireattys (as in Pausanias, I, 28, II), or Phreatto. Aristotle, Constit., 57, 3, gives the genitive Phreattow, followed by Theophrastus, quoted by Harpocration, s. $v$. lts location is not exactly known, but it lay somewhere near the sea at the Piraeus, as Pausanias says, 1, 28, II. Milchhöfer, Karten von Attika, Erl. Text, I, pp. 56 and 59 , identifies it with the outermost point of the peninsula which bounds the harbor of Zea on the east, where he found an oval depression in the rock, which he took to be the basin for washing and preparing the purple shell; cf. H. Blümner, Technologie, I, pp. 230 sq. This would explain the name as "Place of Pits." However, H. N. Ulrichs, Reisen und Forschungen in Griechenland, I, 173 sq., followed by Wachsmuth. Die Stadt. Athen, I, 325, places it at a point on the shore southwest of the entrance to $\mathrm{Zea}$, where 2 bath-like oval depression with a small round hole in front has been found. On the legendary origin of this court, see Pausanias, $I_{z} 28$, II, and $c f$. Philippi, op. cit., pp. 18-19.

20 Aristotle, Constit. 57, 3; Demosth., 23, 77-78; Pausanias, I, 28, 11 ; cf. Aristotle, Politics, III, I3, 2, p. 1300 b 29 ; Bekker, Arecd. gr. I, 3II, 17; Photius, $535 \mathrm{a}, 28$. No trace of this court appears in the Draconian tablet.

27 Aristotle, Constit., 57, 3; Demosthenes, 23, 78, says he must plead from a boat which does not touch the land; Pollux, VIII, 120, adds that the accused cannot cast anchor or put down a gangplank during the trial; of course, this was because of the pollution which his contact would extend to the mainland; see the next note.

"Demosth., 23, 78. The orator says the framer of such an ordinance did not overlook the case of a criminal just because he was unable to come to Athenian soil, but found the means of "keeping religion unprofaned"; he adds that the "contriver thought it was the same impiety to 
The last of these courts was the one held at the Prytaneum. ${ }^{125}$ The curious trials held here are mentioned by many Greek writers and appear to have comprehended three kinds of cases. In the first place, if a murderer were unknown or could not be apprehended, he was nevertheless tried here; ${ }^{120}$ secondly lifeless things-such as stones, beams, pieces of iron, etc., which caused the death of a man by falling upon him, ${ }^{1 * \pi}$ and, finally,

leave a guilty man at large as to give up an innocent man for punishment before trial." (Secs. 78-79.)

${ }^{23}$ To dikasticrion epi Prytaneioi. The Prytaneum was the Hotel de $V$ ille of Athens as of every Greek town. Its site is not fully established. It is generally supposed that in the lapse of centuries several buildings bore the name. Many scholars believe the original one of the royal period stood on the Acropolis. In Pausanias' day it certainly was on the north slope of the Acropolis, a little to the east $(1,18,3: c f$. Judeich, Rheinisches Muscum, XLVII, 55), and near the top (Pausanias, I, 18, 4; cf. Gerhard, Philologus, IV, 382: Bursian, Geographic von Griechenland, I, 295 : Petersen, Archacol. Zcisung, X, 412: Wachsmuth, Die Stadt Athen, I, 221 sq.: Harrison, Ancient Athens, 165-168). Bötticher believed he had found remnants of it there: Philologus, Suppl., Bd. I, III (1867), 359 sq.: for the position, see Curtius, Topographie, Karte VI (at the end of his Stadtgeschichte von Athen; reproduced in Hitzig-Blümner, ed. of Pausanias, I, Tafel 2); but Milchhöfer, Baumeister's Denkmäler, 1, 172, says no remnants are visible. For the elaborate theory of E. Curtius, that the Prytaneum in the regal period stood on the Acropolis, but later was transferred to the old agora (which he assumes was south of the Acropolis following Thucydides, II, 15), and lastly was moved to the position given by Pausanias on the north slope of the Acropolis, see his Stadtgeschichte (1891), pp. 51, 60, 224-225, 302; and cf. his Attische Studien (1863-1864), II, 62, 65; this theory was accepted by Schöll, Hermes, VI (1872), p. 19; Hageman, $D \mathcal{E}$ Graccorum prytaneis ( $188 \mathrm{1}), \mathrm{p}, 22$ sq. and Marindin, in Smith's Dictionary of Antiquities (3rd ed.), 2, p. 514. The theory has been attacked by Bursian, De foro Athen, 13: by Lolling, Hellen. Landeskunde und Topogr. (Muiller's Handbuch, III, p. 320, 3) ; and by others. Modifications of his view have been made by Polant, Griech. Studien, H. Lipsius dargebracht (1894), p. 85; Dörpfeld, Athcn. Mitth., XVII, 439 and XIX, 143; XX, 185. Lipsius believes the court in question was always in the agora, wherever the building was: Das Aitische Recht und Rechtsuerfahren, I, p. 58 (based on Meier-Schömann, Der Attische Process, ed. 2, 1881-1886). Though the arguments of Curtius and Polant seem plausible, there is no real evidence, however, that the Prytaneum after the.royal period ever stood anywhere but on the north slope of the Acropolis: see Frazer, Pausanias, Vol. II, p. 172: Wachsmuth, Die Stadt Athen, I, 46; and for a discussion of its location, see Hitzig-Blümner, $o p$. cit., $I, I$, pp. 211,212 and $c f$. p. 316 .

${ }^{20}$ Aristotle, Constit., 57, 4. Plato, whose striking precepts for his ideal laws were largely taken from existing Athenian laws (see Lipsius, op. cit. p. I3I), gives the procedure more fully; Laws IX, 874 A. Pollux, VIII, 120, also states the law fully.

${ }^{21}$ Demosth., 23, 76 (followed by Harpocration, s. iv. epi Prytaneioi, and epitomized by Suidas. Photius, etc.; s. v. epi Prytaneioi; cf. Etymologicum Magn, 362, 55; Bekker; op: cit., 31 r, 15: Aeschines, 3. 244: Pausanias, I. 28, 10. Aristotle, Constit., 57, 4; Pollux, VIII, 120. Plato, who gives the law in full. exempts from its operation thunderbolts or "other fatal 
animals which eaused the death of men stood trial here. ${ }^{128}$ In order to understand the issues raised by cases of this kind, we must keep in mind the Greek view of homicide, outlined at the beginning of this paper. Manifestly the second case (and probably the third) was merely an amplification of the first: if the human murderer could not be found, the thing or animal which had been the agent in the slaying, if it could be found, must be tried. For in the case of a murder not only had a crime been committed, but a pollution had been brought to the community and some person, animal or thing was to blame and had to be punished before the defilement could be removed. A good idea of the Greek view that some person or thing was responsible is furnished by the subject matter of Antiphon's Second Tctralogy already mentioned. Here a boy was killed by running in the way of a javelin hurled by a youth practicing javelin throwing in the gymnasium. The boy's father accused the youth of accidental homicide. The question to be decided was, who was to blame? Manifestly it was either the boy or the youth, or if neither of them, the javelin. If either of the first two, the case (as actually happened) would be referred to the court at the Palladium, where cases of unpremeditated homicide were tried. If it were the javelin, the case would be assigned to the court at Prytaneum. The judges were not concerned with the question of how far either boy or youth was to blame: they merely had to decide who caused the death and the existing laws fixed the penalty. We must not think there was any lack of seriousness in the Greek view-point; we need only recall that Pericles and Protagoras are said to have spent a whole day arguing a. similar question. ${ }^{120}$

We have but little information as to how these trials were conducted. From a hint in the passage from Plato in reference to the trials of unknown murderers (Laws, IX, 874), we infer that the procedure at the Prytaneum was similar to that in the other murder courts. In the first case, where the murderer could

darts from the gods," and makes no distinction between men falling upon the thing or the thing falling upon them: Laws, IX, $873 \mathrm{E}, 874 \mathrm{~A}$.

120. Aristotle, Constit., 57, 4: Plato, Laws, IX, $873 \mathrm{E}$.

is Plutarch, Pericles, 36: cf. Jebb, Attic Orators, I, p. 52. 
not be found, proclamation was made not against any suspect by name but in a more general fashion "against those who had perpetrated the deed and committed the murder." 130 Though the culprits-whether present or absent-were solemnly heard and condemned, there seems, as Cauer has shown, ${ }^{131}$ to have been no proper decision (diagnonai) as in other trials, owing to the fact that such trials were more religious than judicial in character, more like the deodand trials of England. We know that the tokens of slaying, as well as animals, when found guilty, were. cast beyond the borders, to free the land from pollution. ${ }^{132}$

Whether the court before which, according to the general assumption based on the amnesty law of Solon, ${ }^{133}$ trials of conspiracy against the State (tyrannis) were tried, was identical with the Prytaneum court under discussion cannot be decided on the present evidence. That the word "the condemned" (katadikasthcntcs) used in the passage of Plutarch cited refers to the companions of Cylon, who in 6i2 B. C. tried to seize the Acropolis with the intention of setting up a tyranny, is generally assumed. ${ }^{134}$ Now in another passage Plutarch says the remnants of the conspirators, still under pollution, were persuaded by Solon to be tried by a court of three hundred nobles and that all were found guilty and exiled, even the bones of the dead being dug up and scattered beyond the borders. ${ }^{135}$ Many scholars believe that this decision was handed down by the Areopagus and that all such trials were held there. ${ }^{130}$ Others speak for

${ }^{20}$ Demosth., 47, 69: cf. Aristotle, Constit., 57, 4

"Verhandlungen der 40 Philologen-Versammilung zu Görlitz, 110.

20 Aeschines, 3, 244: Pollux, VIII, 120: Pausanias, VI, 1I, 6 ( = the

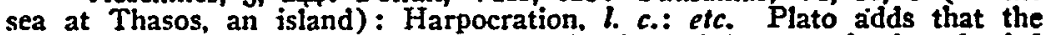
unknown murderer, if later found, "shall die and be cast forth unburied beyond the border"; Laws, IX, 874 A.

"27 Plutarch, Solon, 19 (= Solon's I3th table) . . . plën hosoi . . . ek Prytanciou katadikasthentes hypo ton basileon $\cdot . \cdot$ epi tyrannidi, Here the word order shows that cases of this kind were tried at a prytaneum: $c f$. Andocides, I, 78 , and on the Amnesty law, see Philippi, Rhcinisches Museum, XXIX (1874), pp. I8 sq.

${ }^{22} C f$. Herod, V, $7 \mathrm{r}$ : Thucydides, 1,126 , etc.

20 Solon, 12.

20 So Lipsius, op. cit., p. 23, following the earlier opinion of Westermann, Berichte der sächs. Gesellsch. der Wissensch. (1849), pp. 15I sq.; cf.. Gleue. De homicidarum in Areopago Atheniens. iudicio, p. 10, who followed Stahl, Rhein. Museum, XLVI (1891), pp. 48I sq., who based his 
the identity of the.two courts; ${ }^{137}$ still others are content to leave the question in doubt. ${ }^{138}$ It is only of importance to us here in our later discussion of the age of the Prytaneum court. It would seem impossible to get any other meaning out of the words "by the kings" (hypo tōn basilcōn) in the amnesty law quoted, than to refer them to the tribe kings, who, as we know from Aristotle, were in charge of the Prytaneum court.

Down to the fourth century B. C. the courts at the Palladium and Delphinium seem to have kept their importance. ${ }^{130}$ Though in early times the Prytaneum court also, because of its religious character, may have been important, it, like that of the Phreatto, must gradually have lost its importance. In Aristotle's day it still continued, as we shall see, under the old religious supervision of the King-archon and his associates. In his Politics, however, the philospher makes no mention of it in his enumeration of eight necessary courts, ${ }^{140}$ which proves that it had by then outgrown its usefulness. In this same passage Aristotle also mentions disparagingly the court of the Phireatto and says: "There may be a fourth court in which murderers who have fled from justice are tried after their return; such as the court of the Phreatto is said to have been at Athens. But cases of this sort rarely happen at all even in large cities." 14i In primitive days, when men still had animistic conceptions of nature, trials of lifeless things must have had a greater im-

conclusion on a statement to that effect found in the Scholium on Aristophanes' Equites, 445. Lipsius, p. I3I, believes the prytaneum mentioned in the Annesty law of Solon was an old court no longer known to us, and that it had to do with the prytanes of the naucraries, and consequently was not identical with the court under discussion. He believes it may have sat at the Prytaneum, an official seat (cf. Aristotle, Constit., 3, 5), and that was composed of the nine archons, sitting with the King-archon as president. Aristotle, $o p$. cit., 8, 4, says the Areopagus tried conspiracies against the state under a law of impeachment enacted by Solon: however, he is here referring to his own day (the fourth century, B. C).

${ }^{m}$ E. g. Keil, Solonische Verfassung, p. 108 sq.; cf. von Schöfer, quoted by J. Miller in Pauly-Wissowa, Realcucyclopädic, Vol. V, 2, p. 1653 ; Bötticher, l. c., p. 347. Photius, s. v. naukraria, says Solon found the Prytaneum in existence: $c f$. also the Etymolog. Magnum, 395, 50.

${ }^{10}$ E. g. Busolt, Gricchische Staats- und Rechtsaliertüner, $2 \mathrm{~d}$ ed., p. 16a.

10 Cf. Busolt, op. cit., $p_{.} 273$ : he believes all the homicide courts were limited in the fourth century $B$. C.

${ }^{310}$ IV, $16,2-4$, p. $1300 \mathrm{~b}$.

14 Jowett's Translation. 
portance and would have been retained down into late times chicfly for conservative religious reasons, until finally they became purely ceremonial in character, a species of mock trial. ${ }^{142}$ However, the court of the Prytaneum, like that of the Phreatto, never seems to have been formally abrogated down to the end of Greek days, as it still was in existence in the second century A. D. ${ }^{148}$

Few examples of these curious trials have come down to us. The only one of the first class - of unknown murderers-known to me is found in an oration of the Pseudo-Demosthenes. ${ }^{1+4}$ Of the third kind of case, the trial of animals, no examples are known, and, if we except the trial of the axe of the first ox-slayer at Athens at the feast of the Diipolia, mentioned by Pausanias, ${ }^{143}$ none of the second. But that there were similar courts for the trials of inanimate things in other parts of the Greek world, is evidenced by a few examples, though they are vouched for by late writers. This shows that the same primitive animistic conception of nature was characteristic of the Greek mind gener-

${ }^{10}$ All modern authorities emphasize the ceremonial character of these trials: Philippi, Der Areopag und Epheten, p. 16: Busolt, Staats- und Rechtsaltertümer, p. 273: Meier-Schömann, Griech. Rechtsaltertümer (4th ed., 189\%, by Lipsius), I, p. 512: "endlich beim Prytaneion zenrde nicht sowohl ein wirkliches Gericht gehalten als viclmehr eine religiöse Ceremonie vorgenommen." Pauly-Wissowa, op. cit., II, I, p. 284; Gilbert, Handbuch, I, 430: Lipsius, op. cit., p. 131: Smith, Dictionary of Antiquities, see article "Prytaneum": E. Curtius, Die Stadtgeschichte von Athen, I, 302, sq.; etc.

1a Pausanias, I, 28, 10.

${ }^{24} 47$ (Against Euergus and Mnesibulass): its-feeble and loose style shows it is not by the great orator, but by a contemporary. This was a proceeding against the defendants in giving false testimony in a trial between the plaintiff and the brother of Euergus. In the plaintiff's absence from home, the two defendants entered the apartment of his wife and children, and, while trying to steal some furniture, so injured an old freed woman who resisted them that she died in a few days. The plaintiff went to the legal interpreters (the exiggztai, who expounded the law at Athens like the Roman interpretes religionum; of. Aristotle, Constit., I1, 1; Isaeus, 73, 24: Plato, Euthyphro, 4 D and 9 A: Laws, 759 C-E and 775 A), who stated the law to him and advised him, since he was not present at the time, and only had his wife and children as witnesses, "not to make a proclamation against any one by name but generally against those who had perpetrated the deed and committed the murder." (Sec. 69.) However, the case does not seem to have come up for trial at the Prytaneum, for the plaintiff was further advised to bear his misfortune and to perform the necessary religious ceremonies.

sas $1,24,4 ;$ cf. I, $28,10$. 
ally. ${ }^{140}$ The best example of such a trial is that of the statue of Theagenes, the most famous of the Olympic victors, ${ }^{147}$ on the island of Thasos. ${ }^{138}$ For an exhaustive account of the trials held at the Prytaneum, from which the present brief one is taken, the reader is referred to a recent article by the author. ${ }^{140}$

After this description of the jurisdiction of the five murder courts, our last problem will be to discuss their age and management.

The Council of the Areopagus, in origin and character, was very similar to the old Council of Chiefs which we find among the early Romans, Teutons, Celts and other primitive peoples. During the royal period at Athens it must have greatly resembled the Council of Elders described in the Homeric poems'and it must have played an important role in transforming the city from a kingdom to an aristocracy in which it was to be supreme.

${ }^{20}$ We also know that the nurder procedure of Athens was imitated hy other Greek states: see Isocrates, Pancgyr., $40 \mathrm{~K}$ 10; cf. Gilbert, Handbuch, p. 535 and Lipsius, op. cit., p. 6rg; ctc.

${ }^{102} \mathrm{He}$ won in boxing in O1. $75(=480$ B. C.), and in the paniratium in Ol. 76 ; he won in other contests many times, receiving 1400 crowns in all according to Pausanias, VI, 11, 15, or 1200 according to Plutarch; Pracept, rcipublicae gerendac, 15. For his exploits see Pausanias, VI, II, 2-9; cf. Förster, Die Sieger in den Olympischen Spielen, nos. 191-196, and Hyde, De Olympionicarum Statuis (Halle, 1903), no, 4 : etc.

3i. Pausanias, l. c. recounts how a former enemy of the victor used to come each night after his death and scourge his statue as if he were punishing Theogenes himself. Finally, the statue checqued his insolence by falling upon him and killing him. The man's son prosecuted it for murder, and 'it was' found guilty and cast into the sea. Later on the lands of Thasos became unfruitful and the Thasians were advised by the Delphic oracle to bring back their exiles. After doing this, the dearth kept up and they were again advised in these words: "But you have forgotten your great Theagenes." They did not know how to recover the statue, but fortunately it was caught in a fisherman's net and towed to shore, and set up in its old place in the agora, where Pausanias says it was sacrificed to in his day as to a god, VI, ii, 9 . Similar examples occur in Greek literature, but this appears to be the only case in which an actual trial and condemnation is recorded: $c . g$. the statue of another Olympic victor, Euthymus of Locri (who won in boxing in Ols. 74-77: Paus., VI, 6. 4: Hyde, op cit. 56: Forster, op. cit., nos. 185, 195, 207), had a similar history to that of Theagenes: Eusebius, Praep. cvang., V, 34, p. 232 b, d. Another example is that of the bronze ox of Philesius at Olympia, set up as a votive offering of the Corcyraeans, which caused the death of a small boy playing beneath it, who, on suddenly raising his head, broke it against the belly of the ox: Pausanias, V. 27, 9-10: of. $\mathrm{X}, 9,3$.

"The Prosecution of Lifeless Things and Animals in Greek Law; American Journal of Philology, XXXVIII (1917), 2, No. 150, pp. 52-175, and 3. No. I5I, pp. 285-303. 
For the pre-Draconian period Aristotle states that the Areopagus appointed all officers, administered the government and guarded the laws, having the power to fine or punish all who violated the laws as well as those who were convicted of immorality. ${ }^{150}$ The remmants of political power which continued to cling to it many centuries later, after its importance had waned, is corroborative of this evidence, as is also the fact that the name "Council" was retained, which shows that the later body was formerly a State Council. The Areopagites were appointed from the archons by birth and wealth, ${ }^{151}$ and this method of election endured to the beginning of the fifth century, when it was replaced by lot. ${ }^{182}$ Under Draco it remained "the watcher of the

${ }^{20}$ Constit., 3, 6: cf. 8, 2: Isocrates, 7, 46: Androtion and Philochorus (Müller, Fragm. Hist. Graec., 1, p. 387,17 and p. 394, 60). Curiously neither Herodotus nor Thucydides say anything of its powers; however, they had no special reason for mentioning it, and before the fourth century B. C. there was no interest in the constitutional antiquities of the Greek states. In a passage which bears on the early constitution of Athens, Thucydides, 1,126 , says that during the Cylonian insurrection (end of the sixth century B. C.), the nine archons were entrusted by the Athenians with absolute power to deal with the conspiracy at discretion; this however, is not out of harmony with Aristotle's view of the early supremacy of the Council, for it is possible the administration of the archons may then have been under its supervision and already a popular modification of the Council may have taken place; see Botsford, art. Arcopagus, in the Encyclopedia Britannica (IIth ed.), II, p. 453 and n. t. The Eumenides of Aeschylus, written in the early part of the fifth century B. C., is a glorification of the Areopagus, especially of its judicial importance.

ss Aristotle, Constit., 3, 6 (speaking of the pre-Draconian age): such a statement destroys the older views of the connection of the cphetai with the Areopagus: cf. e. $g$. the view of Lange, Abhandlungent der Sachs, Gesellsch. der Wisseuschaften, VII, I99 sq.

${ }_{132}$ Despite Aristotle's statement, Constit., 8, 1, that Solon chose archoss by lot from nominees chosen by the tribes, each choosing ten. This appears to be a mistake, for Aristotle merely inferred that the method in vogue in his day was the same as in Solon's day. In another passage, 22, 5, he corrects it by saying that the nine archons were appointed by lot by the tribes from 500 nominees chosen by the demes, and that this was the method in the Archonship of Telesinus $(487-486$ B. C). It was this change which made the archons of little influence, for their old powers as chief magistrates thus went over to the generals. For the sake of clearness, it should be added that the archonship was founded about $700 \mathrm{~B}$. C., and was followed by the appointment of a polemarch; thus Aristotle, Conslit., 3. 2-3. says the most important three officials of Athens before Draco were the King (archon), polemarch (in charge of war affairs), and the archon. He gives five stages in passing from royalty to aristocracy. Thucydides, I. I26. speaks of the nine archons collectively, but the responsibility in regard to Cylon's conspiracy was taken by one. Aristotle says that down to Solon's day the archons had no official residence, but later used the Thesmotheteum, while the king used the Boucoleum, the archon the Pry- 
laws" and saw that officials acted legally; for whoever was injured by them could bring his case before the Areopagus. ${ }^{153}$ Under Solon it returned to its constitutional powers, though his reforms tended to limit them. (594 B. C.) In one respect Solon increased its powers, giving to it the privilege of trying cases of conspiracy. ${ }^{154}$ It recovered its administrative powers to a large extent after the Persian Wars. ${ }^{155}$ As protector of the laws it probably always had the power of inhibiting both in the Assembly and later in the Council of Four Hundred any measure it conceived to be disadvantageous to the state. As moral censor it knew men's incomes and punished the idle. ${ }^{250}$

We are here, however, concerned only with the judicial functions of the Areopagus-its jurisdiction over murder. When it received this prerogative cannot be stated with certainty, though the view that Draco found this already in existence is scarcely questioned. ${ }^{157}$ That Draco fixed in his murder code the distinctions in cases for all later time has alreardy been shown; but how far back of his time such distinctions go, we cannot say. The myths of the origin of the judicial powers of the Areopagus, ${ }^{158}$ as ivell as hints in the orators founded on them, ${ }^{158}$ point to a great antiquity in the use of the hill of the Areopagus for a tribunal even if not for the Court of the Areo-

taneum and the polemarch the Epilyceum: 3, 5. This shows that the collegiate responsibility was post-Solonian. The archonship was opened to the second class of citizens, probably after the Persian Wars, to the third in 457 B. C. (Aristotle, 26, 2); and these officials were elected by vote from 487 B. C. (Aristotle, 22, 5), and later by lot $(30,4)$. Before Aristotle's work was discovered, Grote, Busolt and other writers had maintained that the lot was not used before the time of Cleisthenes. We learn

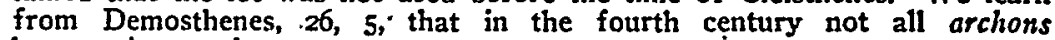
became Areopagites.

${ }^{283}$ Aristotle, Constit., 4, 4: most modern writers consider ch. 4, however, as interpolated: it is too complicated a subject to be discussed here.

15 Aristotle, Constit., 8, 4 and 5.

iss Aristotle, 23, I.

in Plutarch, Solon, 22.

${ }^{207} \mathrm{~J}$. Miller, Pauly-Wissowa, Realcncyclopädic, V, 2, 165I, says this "wird jetzt von kcincr Scite mehr bestritten."

${ }^{2 s}$ Hellanicus, Schol. on Euripides, Orestes, 1648 , gives four typical cases of premeditated murder being tried before the Areopagus in mythical days-those of Cephalus, Halirrothius, Orestes and Daedalus.

2s E. g. Demosthenes. 23, 66, says: "We are informed by tradition that in ancient times the gods alone demanded and rendered justice at this tribunal of murder." 
pagus. ${ }^{100}$ The first direct evidence that the judicial competence of the Areopagus goes back even to Draco's day is late. ${ }^{101}$ Two late accounts even state that Solon founded this competence. Thus Pollux, a writer of the second century A. D., says Draco instituted the Ephetai and that these judges sat in all the murder courts and that in addition to them Solon instituted the Areopagus. ${ }^{162}$ Similarly Plutarch records that "the general statement is that Solon instituted the Areopagus." 103 He adds, however, that though this statement is apparently confirmed by the fact that Draco in his homicide laws never mentions the Areopagites but only the Ephetai, he is doubtful of it, since Solon's thirteenth table-the amnesty law already discussed-seems to show that the Areopagus already existed before his day. The discovery of Aristotle's Constitution of the Athcnians in $1890^{104}$ has unfortunately added but little to settling this question. It has given us much additional knowledge about the political and administrative history of Athens, but it tells us little of the judicial history back of Aristotle's day. ${ }^{105}$ In one place, how-

${ }^{100}$ Lipsius, op. cit., p. 14, believes all murder trials in early days wereheld on the hill, though not before the Council. Though it is possible that the body which then tried murder cases was not different from the old administrative council (similarly the Spartan Gerousia exercised an administrative and judicial function), still this cannot be proven. Lipsius, therefore, carefully distinguishes between the hill called Areopagus (as a Gerichtsstätte), and the later Court of the Areopagus (Gerichtshof).

202 Demosthenes is the first to explicitly affirm this: 20, 157-158: $12 \mathrm{w}$, 23, 22: cf. 23, 51 and 66. The word dikazein in the Iaw, 23, 22, and elsewhere, shows a late redaction.

10 VIII, 125 (Bekker's edition, 1846).

${ }^{300}$ Solon, 19.

${ }^{304}$ It was found in Egypt at the end of the year: the cditio princeps is that of Kenyon, Jan., 1891. The best annotated edition is that of Sandys, 1912 (2d Ed.) : the best translation is that of Kenyon, 1912 (an earlier one being by E. Poste, 1891). Throughout this paper I have used Kenyon's edition of 1903. Aristotelis Res Publica Atheniensium (Berlin). For bibliography, see Hellenic Cizilization (1915), p. 43. Internal evidence shows that the work was compiled between $328-325$ B. C., some years after the Politics, and shortly after Androtion's Atthis-Aristotle's chief source: see Schwartz, Androtion, in Pauly-Wissowa, op. cit., I, 2173, 5: Keil, Die Solonische Verfassing (1802), pp. Ig0 sq.: and on Philochorus, see especially J. H. Wright, Did Philochorus quote the Athenaion Politeia as Aristotle's? In American Journal of Philol., XII (189r), pp. 310-318. On the Atthid writers in general, see Schwartz, art. Atthis, Pauly-Wissowa, II, 2180-2183; Wilamowitz, Aristoteles und Athen, I, 260-290: Busolt, Griech. Gesch., II, 7 sg.

${ }^{20}$ Constit., 57, 3-4. 
ever, he says the tyrants (560-10 B. C.) left to the Areopagus its murder jurisdiction, which statement would seem to bring the date of its judicial functions back at least to Solon ( 594 B. C.). ${ }^{160}$ On the basis chiefly of the statements quoted from Pollux and Plutarch, the view first propounded in 1833 by Schömann ${ }^{107}$ was long accepted by writers on Greek law, that all murder trials before Draco's day were in the jurisdiction of the Areopagites, but under his legislation were transferred to the board of judges called Ephetai instituted by him, and that later Solon gave back to the Areopagus the most important part, cases of premeditated murder. However, not all writers today accept this statement of the case. Thus Lipsius denies there is any proof that the Areopagus existcd as a judicial body before Solon and believes that the words of Pollux and Plutarch indicate that Solon took cases of premeditated murder from the Ephetai (founded by Draco) and gave it over to the new Council of the Areopagus. ${ }^{168}$ The main contention of Schömann, howover, has recently found a vigorous defender in Gustav Gilbert, one of the foremost experts on Greek legal antiquities. ${ }^{168} \mathrm{He}$ believes the amnesty law of Solon proves that the Ephetai sat in these courts before Solon and believes that the blood process belonged to the Areopagus before Draco. In other words Draco limited the powers of the Areopagus, which before him, and again after Solon, had jurisdiction in murder cases. Under Draco, then, the Areopagus, became, as Aristotle says, merely the

${ }^{108}$ Constit., 16, 8. He says that the tyrant Peisistratus himself, being haled before the Areopagus for murder, presented himself. Demosth., 23, 66, says: "This tribunal [the Areopagus] ncither despot nor oligarchy nor democracy has ventured to deprive of its jurisdiction in murder." The statement in the Politics, II, 9, 2, p. 1374a, which makes the Areopagus antedate Solon, probably only refers to its political activity, as do also certain statements in the Constifution, 3,$5 ; 4,4 ; 8,4 ;$ Lipsius, op. cit., $I$, p. I3, n. 49 , says 8,4 has nothing to do with murder competence.

${ }^{2}$ In his De Areopaga et Ephetis (Opuscula academica, $1, \mathrm{p} 190^{\circ} s q$.): it was later modified by the author in Jahrbuch fïr Philologie, CXI (I875), p. 157.

10 Op. cit., I, p. 20: on page 22 he characterizes Schömann's view as improbable and without grounds for the pre-Solonian murder jurisdiction of the Areopagus.

300 Jahrbuch für Philol., Suppl. Bd., 23: see especially pages 485 sq. and 516 sq. (whole article, pp. .476-507): $c f$. his Handbuch, 1 , 135 . 
"watcher of the laws" and the regulator of officials. ${ }^{120} \mathrm{He}$ is opposed, therefore, to the Draconian origin of the law about premeditated murder, which, as he points out, is omitted in Draco's tablet and is vouched for expressly for the first time by Demosthenes in the fourth century B. $C$.; he believes that premeditated wounding, poisoning and arson were first distinguished as special cases after Draco's legislation and then given over to the Areopagus. He further believes that Draco took over the whole criminal procedure, which he assumes was in the hands of the Areopagus before his day, and gave it to the court of the Ephetai, which he founded, and that it was given back to the Areopagus first under Solon. J. Miller ${ }^{171}$ characterizes this reasoning of Gilbert as possible but incapable of proof. Drerup ${ }^{17.2}$ has shown that a comparison of Aristotle's statements about the functions of the Areopagus, on which Gilbert partly relied, proves nothing, since Aristotle, probably intentionally, speaks of its competence only so far as his authorities come into account. It may, however, be said in favor of Gilbert's reasoning that the words aition phonou in the Draconian Tablet (line 12) and the statement of Pollux are best explained by his assumption, as well as the fact that in cases of intentional and unintentional homicide different courts judged and that nothing is said about the Areopagus in the tablet. Miller and most writers, however, believe that Pollux was mistaken, since in one respect at least we know his statement is incorrect; for he says that the Ephetai sat in all five courts, though we now know they did not sit in one-that of the Prytaneum. It is possible that the Areopagites in their criminal jurisdiction were called Ephetai until after Draco's legislation, ${ }^{173}$ for this assumption . best explains the otherwise obscure statement of Plutarch that Draco only mentioned Ephetai in his murder laws and also the statement of Pollux that the Eplictai sat at the Areopagus as well as in the other murder courts. It is also possible to explain Solon).

"ro See Constit., 4, 4 (for Drảco): 3, 6 (before Draco): 8, 4 (after

in See the article on Drakon, Pauly-Wissowa, óp. cit., p. 1652.

is Jahrbuch für Philologic, Suppl. Bd., XXIV, p. 275.

${ }^{35}$ Cf. Philochorus, Fragm. 88 (= Müller, Fragm, Hist. Graec. 394). 
the absence of reference to the Areopagus in the Draconian tablet by assuming that Solon here substituted his own laws about wilful murder. ${ }^{174}$ Similarly it explains Plutarch's statement that Solon instituted the Areopagus, a notion partly due to the desire of later writers to ascribe to Solon the formulation of a complete constitution. ${ }^{175}$ However, we are not yet in possession of enough knowledge to settle the long disputed question of the relation of the Ephetai to the Areopagus, or to determine with any degree of certainty the time at which the ancient Council of the Areopagus received its judicial functions, though it seems probable that these functions came to it long before the time of Draco.

The history of the Areopagus after Solon is briefly told. As we saw, Aristotle says it retained its murder functions under the tyrants. After their expulsion, in the reforms of Cleisthenes (508 B. C.), the Council seems to have received no abridgement of these powers. After Cleisthenes, however, it slowly changed its character through the annual admission of exarchons who had held office under a popular regime. By 487 B. C. its powers waned because of the introduction of the lot in the selection of archons. In the year 462 B. C., the democratic leader Ephialtes, in conjunction with Archestratus and Pericles, passed measures by which most of its administrative functions were given over to the Council of Five Hundred, the Assembly and the popular law courts. ${ }^{178}$ It still retained jurisdiction over wilful murder as well as over all cases in reference to the sacred olive trees. From 462 B. C. to the end of the Peloponnesian War (404) it was of no consequence politically, as the class of citizens known as Zengitae were admitted in 457 and the lot became the method of electing archons. After the appointment of the Thirty Tyrants the law of Ephialtes was repealed and the Areopagus was again

"Cf. Botsford, Encycl. Brit, Irth Ed., II, p. 453

${ }^{23} C_{f}$, the words of Gilbert Murray, in his Ancient Greek Literature, p. 13: "When 2 law was once passed at Athens it tended to become at once the property of Solon, the great "nomothetes."

${ }^{280}$ See Aristotle, Constit., 25, 2: 27, 1: 35, 2: Plutarch, 'Pericles, o. Cases of impiety and the supervision of officials and the censorship of the morals of the citizens were then transferred; see Wilamowitz. Aristoteles and Athens, II, 186-197; Busolt, Greich. Geschich. (2nd ed.), III, 269234. 
made guardian of the laws when the democracy was restored. ${ }^{137}$ From then to the end of Greek history it retained its reputation for ability. ${ }^{17.8}$ Even in the second century of our era it remained a murder court. ${ }^{179}$ Its activity seems to have ended about 400 A. D. ${ }^{180}$

Cases brought before the Palladium, Delphinium and Phreatto were tried, under the presidency of the King-archon, ${ }^{181}$ before a jury of men called Ephetai. ${ }^{182}$ This court of the Ephetai consisted of fifty-one men, ${ }^{183}$ all of whom were over fifty years old and of blameless life ${ }^{184}$ and probably of eupatrid, or noble birth. ${ }^{185}$ The origin of the court, as already dis-

${ }^{\text {sts }}$ Aristotle, Constit., 35, 2. In 403 B. C., by a decree of Tisamenus (cf. Anclocides, 1, 84), it received the guardianship of the constitution.

${ }^{2: 8}$ Cf. Isocrates, VII: Demosth, 23, 65: Valerius. Maximus, 8, 1; Aulus Gellius, 12, 7: Lucian, Bis accusalus, IV, 12, 14: etc. Under Roman sway it led Athens: cf. Cicero, De nafura decorum, II, 74 . Then it received new prerogatives-the trial of forgers and tamperers of the standard measures, the care of education, religion, etc.; cf. Tacitus, Annales, II, 55: Plutarch, Ciccro, 24; Acts of the Aposiles, XVII, 19.

1" Pausanias, I, 28, 5.

${ }^{200}$ Thoedoret, $C_{\text {urat., }} \mathrm{IX} ; 55$.

${ }^{14}$ Aristotle, Constit., 57, 4, says the king presided crowned; in the Draconian tablet the plural (kings) is used, which may refer to the yearly elected king-archons: so Lipsius, op. cit., I; 17-18. Wilamowitz, Aristotcles und Athen, 1, 94, believes the plural includes the king and the tribe-kings together, against which explanation see Gilbert: Jahrbuch für Philologie, Suppl. Bd., 23, 489, n. 2.

The Draconian tablet is warrant for cases tried at the Palladium; lines to sq. (and four other places): Aristotle, Constit., 5\%, 4, says judges chosen by lot (the word Ephetai, if used, was dropped from the manuscript), sit in judgment in the three courts. Cf. Harpocration, Lexicon, s. $v$. ephetai, who wrongly includes the Prytaneum in their jurisdiction: $c f$. Suidas, Photius, etc.

14 The number is given in the Draconian tablet, line 19; Demosth., 43. 57: Pollux, VIII, 125: efc. It is wrongly given as 50 by Timaeus, Lex. Platon. s. $v$. and by the scholiast on Demosth., 23, 37. The meaning - of the number is unknown: Busolt, Griech. Staats- und Rechtsalt., P. I43, assumes it had to do with the three courts at which they sat, seventeen at each. But the Draconian tablet assumes they acted collectively. Busolt, again, Griech. Grsch., and edi., $11,179, n$. 1 , suggests the number may refer to three classes of citizens. Gilbert, Handbuch, I, 136, n. I (following Schömann. Opssscula Acad., I, 196),. believes the number comes from 12 men from each tribe together with three legal interpreters; Lipsius, op. cit., I, I8, explains the uneven number as including the king-archon: in n. 61 he says it is also possible that the uneven number was appointed to avoid a tie.

${ }^{21}$ Efymol. Magn: Photius; Suidas, s. v. ephetai: Bekker, Anecd. gr., I, 188, 30.

${ }_{20}$ Pollux, VIII, 125; cf. Demosth., 43, 57; Aristotle, Constit., 3, I (of Draco's officials). This is Gilbert's explanation of the word aristindên; Handbuch, 136 , n. I; cf. Aristotle, Politics, VIII, 45, 1. 
cussed, is doubtful, though both Polllux and Timaeus assert Draco founded it. ${ }^{180}$ Nothing as to its age can be deduced from the myths of its origin ${ }^{187}$ or its possible etymology. ${ }^{188}$ Philippi was the first to throw doubt on the statement of Pollux that Draco instituted the Ephetai, by showing that he probably made the mistake by a wrong reading of a passage on the Draconian laws in Demosthenes. ${ }^{189}$ Recently Philippi's arguments have been attacked by Gilbert, who as already mentioned, maintains that Pollux' statement that Draco founded the court of the Ephetai is reliable. ${ }^{190}$ Whoever does not follow Gilbert's reasoning, must leave the origin of the court of the Ephetai undetermined. But if the character of the Draconian code is rightly looked upon as in essence a codification of customary law long

- 2se Pollux, VIII, 125: Timaeus, Lex. Plator., 127.

in See Pausanias, I, 28, 8-9 (the account being derived from Clitodemus, according to Suidas, Lexicon, s. v. epi Palladioi): a slightly different version of the myth is given by Pollux, VIII, 118 and the Schol. on Aeschines, 2, 87. Cf. Gilbert, Jahrbuch für Philologie, Suppl. Bd., 23, 497 sq.

2m The ancients derived the word from ephiesthai ("to appeal") : e. g. Pollux, VIII, I25 (followed by C. F. Herrmann, De Dracone legumlatore [185I], pp. 15 sq.: rejected by Lipsius, op. cit., p. $15, n .53$ ). It is more probable that it comes from the same verb in the sense of "to command," and so is connected with ephetme and ephetes (= commander, in Aeschylus, Persae, 79; cf. Wilamowitz, Philolog. Untersuch., I, 90, n. 5). The idea of command at first would have no legal coloring, but later the term would befit a judge's office of giving orders and information ( $=$ "Anweiser des Rechts, Lipsius, p. 15: cf. Schömann, Dc Areopago et ephetis, p. 7 ; Gilbert, Handbuch, I, I37, n. I: etc). Another derivation is given by L. Lange, De ephetarum Atheniensium nowtine (1874), pp. 13-14; cf. Busolt, Griech. Gesch., and ed., II, 234, n. I.

20 Law 43, 57-reading toutois for toutous-d'oi pentekonta kai heis aristindēn haireisthon. The statement in Timaeus can be explained from the same source: Schömann, Jahrb. für Philologie (1875), p. 153, believes this explanation of Philippi is possible but unnecessary. See Philippi, N. Jahrb. für Class. Philol., CV (1872), pp. 578, and especially 604 sq.: cf. his Arcopag und Epheten (18\%4), pp. 139 sq. and 203 sq. In the first article he doubted Pollux's statement about the mode of choosing the Ephetai and in the later book he objected to the statement that Draco instituted the court. He was followed by Lange, Die Epheten und der Areo. pag, p. 3 sq.: by Wachsmuth, Dic Stadt Athen, I, 479. I: Wecklein, Sitzungsberichte der bayr. akad. (1873), 5-6. J. Miller, Pauly-Wissowa, op. cit., V. 2, 2825 (art. Ephetai), says Philippi's argument "ist sum mindestens sehr wahrscheinlich."

${ }^{100}$ Handbuch, I, I36, n. I: he characterizes Philippi's reasoning as "möglich, abcr nicht notwendig": cf. his article in Jahrbuch fiir Philol., Suppl. Bd., XXIII, $493 s q .:$ he followed Schömann in the first edition of his Handbuch, but later changed his view on the basis of statements in Aristotle's Constitution. Busolt also believes Draco founded the court, Staats- und Rechtsalt., I, p. 273. - 
in the making, as most scholars today believe, ${ }^{101}$ then the statements of late writers, like Pollux, that Draco fotinded the Ephetai, lose their interest. In any case it is probable, as we have shown, that in the oldest times a court on the Areopagus had charge of all murder cases, both premeditated and unpremeditated. Whether the Areopagites were then called Ephetai or whether judges of this name were later appointed by Draco to render the work of the Areopagus easier, or perhaps to limit its functions, ${ }^{192}$ cannot be stated with any degree of certainty. But as degrees of guilt slowly grew and began-to be definitely conceived, cases of homicide would naturally, have been taken from the Areopagus and tried by the later court of judges, the Ephetai, who would sit, as the nature of the case demanded, in the different localities-at the Palladium, Delphinium and Phreatto.

The court of the Ephetai, whatever its origin, remained unchanged in its composition and form at least down to $409-8 \mathrm{~B}$. C., as we conclude from its being mentioned in the Draconian revision of that date. It appears, however, to have gradually lost in reputation, as we learn from a statement of Pollux. ${ }^{198}$ A change certainly took place soon after $408 \mathrm{~B}$. C., for Isocrates, in a speech made shortly after 403-2 B. C., mentions 700 judges in a process before Ephetai. ${ }^{194}$ Consequently this change took place somewhere between 408 and 402 B. C., and probably after the fall of the Thirty Tyrants in $404 . .^{195}$ By Aristotle's day, if not by the beginning of the fourth century B. C.,

${ }^{m}$ E. g. Lipsius, I, pp. I6-17; p. I9 reads: "darf man auch hier der Annahme sich zuneigc dass Drakon nicht sowohl neues Recht geschafft als bercits bestehendes sanktioniert hat," ${ }^{2}$. s. w. Gilbert's idea is different, as we have seen, and he is followed by the anthors of the Recueil already mentioned.

${ }^{20}$ So Wilamowit2, Aristoteles und Athen, II, 199; cf. Gilbert, Jahrbuck für Philol., Suppl. Bd., XXIII, p. 492 sq.

${ }_{120}$ VIII, 125: Miller, Pauly-Wissowa, op. cit., V, 2, p. 2825, believes this statement refers to the period before $409-408 \mathrm{~B}$. C.

${ }^{23} 18,54$ Demosthenes, 59 , ro, names one of 500 dicasts trying a homicide case.

${ }^{3 *}$ Cf. Philippi, op. cit., 318 sq.: Keil, Solonische Verfassung, io6 sq.: on p. IIo the latter connects this change with the psephisma of Patrocleides (cf. Andocides, I, 177), and he believes that the Ephetai were first removed from the Delphinium: Gilbert, on the other hand, believes that they were first removed from the Palladium about $400 \mathrm{~B}$. C., and later from the, Delphinium and Phreatto, being replaced in all these courts by heliastic or popular jurors. . 
judges in these three courts were chosen by lot; whether they were still called Ephctai or Hcliasts cannot be decided. ${ }^{108}$ Thus we may conclude that from Draco's day, if not earlier, the Ephetai sat in the three courts under discussion. ${ }^{107}$ Draco could hardly have instituted the body; he probably, as noted above, merely systematized the procedure, since the development of the murder process over a long period of time needed clarification. Slowly heliastic courts of democratic origin selected by lot and not through influence arose and took over these functions. ${ }^{108}$.

Lastly, let us briefly consider the age and management of the fifth court, that at the Prytaneum. ${ }^{198}$ Pausanias, in mentioning a similar court on the island of Thasos, says the Thasians in their laws about lifeless things followed those of Draco in

1se Aristotle, Constit., 57, 4: dikazousi d' oi lachontes tau[t' cphetai?]. Here the word for judges is missing in the manuscript of Aristotle; Kenyon supplied the word Ephetai from the citation in Harpocration, who, he thought, copied Aristotle. Kaibel, however, here inserted the word andres (men): see Stil und Text von Aristoteles' Athenaion Politeia, 240; Gilbert, Jalrbuch für Philologie, Suppl. Bd., XXIII, 424, n. 2, inserts dikastoi or héliastai (dicasts or heliasts). Lipsius, op. cit., I, $130, \mathrm{n}$. 30 , says the missing word cannot be ephetai, as that is excluded by the word lachontes ("chosen by lot"), which points to popular jurymen (heliasts), despite the opinion of Keil : op. cit., p. 107 sq. I might add that Demosthenes, 23, 38 (cf. Law, 23,37 ), says diagnoskon de tous cphetas, which lends support to the idea that the judges, though elected by lot, $i$. $e$., heliastic jurymen, still kept the old name ephetai.

${ }^{2 n}$ On the Ephetai, see Miller, Pauly-Wissowa, op. cit., V, 2, pp. 28242826; Lipsius, Jahresberichte, XV, 284 sq. (with bibliography); HermannThumser, Griechische Staatsaltertümer, I, 2, 355 sq.; Busolt, Griechische Staats- und Rechtsaltertümer, and ed., pp. 273 sq., and Griech. Gesch., II, 234 sq.: Gilbert, Handbuch, I, and ed, pp. 424 sq.

${ }^{20}$ Of these the greatest was the Heliaea: Pausanias, I, 28, 8: cf. Harpocration, s. $v$. Héliaia. On the name see Wachsmuth, Die Stadt Athcr, 2, $36 \mathrm{I}$ sq.: its location is disputed, but it probably sat on the south slope of the Acropolis: Milchhöfer, Baumcister's Derkmialler, I, p. 200; cf. Gilbert, Hastbuch, I, 438-439; or on the southwest slope, where the later Odeum was: Curtius, Karten von Attika, Erl. Text., p. 56; or near the Agora; Wachsmuth, Die Stadt Athen, II, p. 358 sq.: cf. Judeich, Jahr. für Philol., CXII, p. 748 . It is mentioned by many writers: Aristophanes, Equites, 897 (cf. Schol. on 898 and on the Vespae, 88 and 772, and Schol. on Demosth; 24,21 . The regular number of jurymen in the fifth century $B$. C. was 6000 (Áristotle, Constit. 24, 3), elected by $\operatorname{lot}(27$ ibid., 4), from citizens over thirty (Pollux, VIII, I22). After Pericles day it was subdivided into bodies of 500 -with 1500 reserves; each juryman was feed three obols (Equites, 255) : see Wachsmuth, op. cit., II, pp. 358-365: Busolt, Griech. Stants- und Rechtsalt., II, p. 275: Gilbert, Handbuch, I, 438-439.

20 For fuller particulars see the article by the author already noted in Amer. Journ. Phit. (1917), Vol. 38, no. 3, pp. 285-286, and 290 sq. 
Athens. ${ }^{200}$ In another passage he connects the origin of the Athenian court with the Bouphonia or ceremonial slaying of an ox at the annual festival of the Diipolia held on the Acropolis, which he says goes back to the age of Erechtheus. ${ }^{201}$ At this festival in honor of Zeus Polieus a curious ritual took place, in which barley mixed with wheat was placed on an altar and an ox, which was kept for the purpose, approached the altar and ate of the grain, whereupon a priest named "ox-murderer" slew it and threw away the axe and fled as if -he were guilty of homicide. The citizens, as if they did not know who did this deed, brought the axe to trial. ${ }^{202}$ In the article already mentioned ${ }^{203}$ I have shown that the trials held at the Prytaneum could have had nothing to do with this festival of the Diipolia, the peculiar features of whose ritual must be sought rather in some form of totemism or allied primitive fact, ${ }^{204}$ while the trials of animals surely go back to an animistic origin. Whatever the date of the founding of the other Athenian murder courts, whether they go back only to the legislation of Draco or earlier, we can be sure that the ceremonial trials held at the Prytaneum must have existed from remote times, for the ideas underlying them are based on the very primitive notion that things and animals are responsible agents. Such animistic notions of nature belong to the infancy of races as well as of individuals. It is in no wise strange that a people, who saw something divine in every fountain, river and tree, should have endowed all common things with life and animals with responsible intelligence.

tw VI, I1, 6: Similarly the Schol. on Aeschylus, Seplem, 179, says the court was Draconian in origin.

$=1,28,10$.

For the ritual, see Pausanias, I, 24, 4: Porphyry, De Abstinertia, II, 30 (taken almost verbatim from a lost work of Theophrastus, reconstructed by 1 . Bernays under the title Theophrastos' Schrift über Frommugkeit, Berlin, 1866); cf. Aelian, Var. Hist., VIII, 3.

${ }^{\infty}$ In the Amer. Joum. Philol., 1917, Vol. 38, no. 2, pp. 152-167, and especially no. 3 , p. 298 .

On the subject, see A. Mommsen, Feste der Stadt Athen in Altertum (1898), pp. 512 sq.; cf. his Heortologie (1864), pp. 449-454; Mannhart, Mythologische Forschungen, pp. $5^{8}$ sq.: Bötticher, Philologus, Suppl. Bd., III (1878), pp. 351 sq.: cf. Philologus, XXII, pp. 262 sq.: Robertson Smith, Religion of the Semites, and ed., pp. 304 sq.: Frazer, The Golden Bough, and ed., pp. 298 sq.; Farnell, Csilts of the Greek States, I, App. to Chap. IV, pp. 88 sg. 
The strange thing is that such primitive ideas should have clung to the Greek imagination throughout the history of the race and should have been countenanced by their greatest thinkers. It is only when we understand the conservative spirit of Greek religion and ritual that we see how such ideas could be retained. We know similar beliefs are characteristic not only of primitive peoples today, but leave their traces among those most civilized. The numerous prosecutions of animals before state and ecclesiastical courts of Europe recorded from the ninth to the twentieth centuries, ${ }^{205}$ show to what extent the idea of the moral responsibility of animals may develop. The laws of deodand in England, whereby personal chattels, such as carts and wheels, which had caused the death of a man, were "forfeited to God, that is to the King, God's lieutenant on earth, to be distributed in works of charity for the appeasing of God's wrath," 206 which laws were not repealed until Victoria's reign, ${ }^{207}$ show how far animistic notions may survive among a highly cultured modern people.

The object of Plato's ideal legislation about the trial of things and animals was the same as that which lay. at the bottom of all Athenian murder trials, i. e., the appeasing of the Erinys or avenging spirit of the dead man. ${ }^{208}$ If this were not done and every attempt made to bring the murderer to justice, calamity was sure to befall the community. ${ }^{200}$ In the last analysis, then, it resolves itself into nothing less than the lex talionis, the oldest and deepest rooted in human nature of all laws; axiomatic in

${ }^{20}$ See E. P. Evans, The Criminal Prosecution and Capital Purishment of Aninuals, 1906: W. W. Hyde, The Prosecution of Aninals and Lifeless Things, in the Middle Ages and Modern Times, 64 UNIV. OF PA. LAW REv. 606 sg. (May 1916).

See Cope: Third Part of the Institutes of the Laws of England (1680), p. 57; cf. Blackstone, Commentary on the Laws of England, Bk. I, Chap. \&

${ }^{207}$ In the year 1845: see Stephen, History of the Criminal Law of England, III, 78: Pollock and Maitland, History of English Law Before the Time of Edward I, II, p. 473: etc.

${ }^{200}$ The Mediaeval Church taught the same doctrine, merely substituting the daemons of Christian theology for the Furies of Mythology.

. On the Greek idea of national defilement and calamity, see Antiphon, First Tetralogy. A. 'Io: and cf. Second Tetralogy, T 6:"Aeschylus, Eumenides, 815: Sophocles, Oed. Tyr., 25 and tor. 
primitive communities and lingering among those most advanced. Aeschylus vindicated for the Greeks Heaven's way with mortals by his doctrine that the law of "Righteousness" was everywhere. If a man suffers, it is merely the divine Nemesis on sin: if it is difficult to see why this man or that suffers, or suffers beyond the merit of his offence, you nust investigate his family history and then you will be sure to find a commensurate sin somewhere there. Sophocles, also, with his milder view of Fate, had the same belief, though he treated Nemesis as a less prominent agency. Nowhere is the Greek law of "blood for blood" more clearly stated than in a passage of Aeschylus' Choephorae, in which Orestes says:

"Just meed may the unjust obtain!

Earth, and ye powers of Hades, hear my prayer."

to which the chorus answers:

"For law it is when on the plain

Blood hath been shed, new blood must fall."210

Inwoven with this retributive notion was the Greek idea of personifying inanimate objects. ${ }^{211}$ It was the action of the law of reprisal in the case of both animals and things. The animal or thing must suffer because its act had aroused indignation and it was held to be responsible. Westermarck has shown that among nearly all the Aryan nations of ancient Europe, not only among the Greeks, but among the Romans, Teutons, Celts and Slavs, an animal which did an injury was given up to the injured party or his family. Here there was no trial, but it is inconceivable that the animal was given up as compensation; it really was given over for retaliation, so that the victim or his kin might be revenged.212 Thus. Thonissen was wrong in explaining the Prytaneum trials as an attempt to revive in the people

)

no Lines 308 sq. (Swanwick's Translation). Greek literature has many examples of this sentiment: e. g., Xenophon, Anabasis, I, 9, II.

${ }^{\prime 2} E$. $g$. the "unforgetable axe of bronze," in Sophocles' Electra, 484 sq.: of. the Trachiniae, 856-859.

ns Origin and Development of Moral Ideas (Ig06-1908), I, p. 256 (many references). 
a sentiment for justice, since through sad experience thcy had come to know right only as might.213

As for the management of the court of the Prytancum, the question so long discussed as to whether the fifty-one Ephetai had charge of it, ${ }^{114}$ and the discrepancy in two statements of Pollux, who in one place (VIII, 90) says the King-archon, in another (VIII, 120) the tribe-kings (phylo-basilcis) were in charge, have been settled by an authoritative statement in Aristotle's Constitution to the effect that both king and tribe-kings had charge. ${ }^{215}$ Thus, though the Ephctai, in charge of the courts at the Palladium, the Delphinium and Phreatto, were in course of time replaced by heliastic jurymen appointed by lot, in all probability the court at the Prytaneum, owing to the fact that its jurisdiction was limited to rare cases of a ceremonial and religious character, never had anything to do with the Ephetai nor their heliastic successors. ${ }^{218}$ The King-archon, then, true to his inheritance, ${ }^{217}$ had the presidency here as in all the other homi-

${ }^{21}$ See his Le droit pénal de la république Athenienne (1875), p. 414. The same mistaken explanation has been offered for the trials of animals in the Middle Ages: see the author's article in 64 UNIv. OF PA. LAw REv. 606 , already noted, for a résumé of different theories presented to explain these trials in the Middle Ages.

2t As Pollux in one passage says: VIII, 120: cf. Harpocration, s. $v$. ephetai. The mistake probably grew out of the fact that the source of both these writers, Demosthenes $(23,65-77)$, juxtaposed the five murder courts; see Busolt, Griech. Gesch., and ed., II, 234, n. 2.

2357,4 Lipsius was the first to point out that the king and tribekings acted together; Sitzungsberichte der sächs. Gesellschaft der Wissensch. Philol. Histor-Classe ( $189 \mathrm{I}$ ), pp. 4I-52. For the older discussion of the management, see Philippi, Der Arcopag und die Epheten, p. 18 sq.

"Cf. Miller, in Pauly-Wissowa, op. cit., V. 2, p. 1652; Lipsius, however, op. cit., I, pp. 20-21, believes that down to Solon's day the Ephetai sat in all the homicide courts; and on p. 27, n. 85 ( $c f$. p. 13I), he says they may have sat in the Prytaneum even down to Aristotle's day, when they may have been replaced by the king and tribe-kings. This is directly at variance with Aristotle's statement and the probabilities of the case.

${ }^{21}$ After the passing of royalty, the royal name was retained as kingarchon (archon basileus), since on him devolved the sacred rights connected with the old name of king; he was in charge of the Eleusinian mysteries, the Lenaea, Anthesteria, sacrifices, games, etc.: sce Aristotle, Constit., 57, I: Pollux, VIII, 90: cf. Demosth., 35, 48 and 399 . The eponymous archon, on the other hand, was the guardian of orphans, widows, heiresses, etc., a sort of Lord Chancellor: see Demosth., 35, 48; law, 43, 75: Aristotle, Constit., $56,6$. 
cide courts."1s In early days doubtless the court at the Prytaneum was important; but gradually it lost its influence. In primitive days, when men hold animistic notions of nature, the trials of things must have been common. They were retained because of their ceremonial and religious character to the end of antiquity. The four Ionic gentile tribes of Attica, dating from the remotest antiquity, ${ }^{210}$ had gradually lost all political significance and their chiefs, $i$. $e$., kings, finally retained only religious functions. Sitting in judgment at these trials was probably their last function historically.

Walter Woodburn Hyde.

\section{The College,}

University of Pennsylvania.

sr Aristotle, Constit., 57, 2: Harpocration, Suidas, s. v. hegemonia dikastzrion; Bekker, Anecd. gr., I, 310, 6 sq.: etc.

${ }^{219}$ The population of Attica was originally divided into four tribes, Geleontes, Hopletes, Acgicores and Argades, each being presided over by its king. Aristotle, Constit., 41, 2, in enumerating eleven changes in the Athenian Constitution before his day, says the people in the days of Ion were divided into tribes and chose kings. The origin and functions of these kings are little known: they probably from the first enjoyed both religious and legal functions, especially the supervision of sacrifices: $c f$. Pollux, VIII, iii: Aristophanes; Fragm., 349: Busolt, Griech. Staats- und Rechtsalt., p. 273 . 